\title{
DOĞU AKDENIZ'DE SALGIN HASTALIKLARLA MÜCADELE: KLAZOMEN (URLA) TAHAFFUZHANESİ
}

\author{
Ufuk Adak*
}

\begin{abstract}
Öz
Doğu Akdeniz’in önemli liman kentlerinden biri olan İzmir, 19. yüzyılda Osmanlı Devleti'nin başlıca ticaret merkezlerinden biriydi. Bu yüzyılda özellikle vapur ve trenlerin kullanımının yaygınlassması ile birlikte artan insan hareketliliği, İzmir'i Akdeniz karantina ağında oldukça stratejik bir konuma getirmiştir. Bu makale, 19. yüzyılın ikinci yarısında inşa edilen Klazomen (Urla) Tahaffuzhanesi'nin kolera ve veba gibi bulaşıcı hastalıkların önlenmesinde oynadığı rolü uluslararası karantina uygulamaları ve kamu sağlığı veçhelerinden ele almaktadır. Klazomen Tahaffuzhanesi, özellikle salgin hastalık dönemlerinde ve insan hareketliliğin yoğun olduğu Hac zamanında Doğu Akdeniz’in başlıca sterilizasyon ve sağlık merkezlerinden biri haline gelmiştir. Özellikle etüv gibi yeni sağlık teknolojileri İstanbul'daki Kavak Tahaffuzhanesi'nden sonra ilk kez bu tahaffuzhanede kullanıma girmiştir. Bakteriyoloji, hijyen ve kamu sağlı̆̆1, 19. yüzyıl devletlerinin ortak gündemidir. Osmanlı yönetimi, bulaşıcı hastalıkların yayılmasını önlemek için bir seri nizamname yayımlayarak, tahaffuzhaneler ile kamu sağlığının korunmasını sağlamış ve salgın hastalıkların özellikle devletin merkezi olan İstanbul'a sirayet etmesini önlemeye çalışmıştır. İmparatorluğun aldığ1 bu sıhhi tedbirler ile tebaanın talepleri bazı durumlarda örtüşmemektedir.
\end{abstract}

Anahtar Kelimeler: Urla (Klazomen), Karantina, Bulaşıcı Hastalıklar, İzmir, Kamu Sağlı̆̆1

\section{Struggle Against Epidemics in the Eastern Mediterranean: Klazomenai (Urla) Quarantine}

\begin{abstract}
Izmir, the major port city of the East Mediterranean, was one of the key trade hubs of the Ottoman Empire in the 19th century. The increasing human mobility particularly with the usage of steamboats and trains led Izmir to have a very strategic position in the Mediterranean quarantine network. This article examines the role of Klazomen (Urla) Quarantine that played to prevent infectious diseases such as cholera and plague from the
\end{abstract}

* Dr. Öğr. Üyesi, Altıbaş Üniversitesi, Ortak Dersler Bölümü, Gayrettepe Kampüsü, 34870, Esentepeİstanbul/Türkiye, ufuk.adak@altinbas.edu.tr, Orcid ID: 0000-0002-5163-4877 
perspectives of international quarantine applications and public health. The Klazomen Quarantine became the main center of sterilization and health in the Eastern Mediterranean particularly during the epidemics and Hajj when human mobility was intense. The new sanitary technologies such as sterilization machines were used for the first time in the Quarantine after Kavak Quarantine in Istanbul. Bacteriology, hygiene, and public health were the common agenda of $19^{\text {th }}$ century states. The Ottoman government issued a series of regulations to prevent the spread of contagious diseases particularly in Istanbul and attempted to protect public health with the help of quarantines. However, the sanitary precautions taken by the Empire and the demands of subjects did not coincide with each other in some cases.

Keywords: Urla (Klazomenai), Quarantine, Infectious Diseases, Izmir, Public Health

\section{Giriş}

19. yüzy1, sağlik hizmetlerinde ve hifzıssıhha uygulamalarında profesyonelleşmenin yaşandığı bir yüzyıl olmuştur. ${ }^{1}$ Özellikle bulaşıcı hastalıklara (emrâz-ı sâriye) karşı alınan sıhhi önlemler arasında sağlık kordonu oluşturulması, karantinaların ve tahaffuzhanelerin inşa edilmesi, etüv ve pülverizatör gibi sterilizasyon ve dezenfeksiyon cihazlarının kullanılmaya başlanması bulunmaktadır. ${ }^{2}$ Bu yüzyılda Avrupa'da toplanan uluslararası sağlık konferansları, bulaşıc1 hastalıkların önlenmesine ilişkin sağlık politikalarının standartlaşmasının önünü açmıstır. ${ }^{3}$ Özellikle yüzyılın ikinci yarısında Avrupalı devletler, Hac zamanında

1 Musa Çadırc1, Tanz̧imat Döneminde Anadolu Kentlerinin Sosyal ve Ekonomike Yapısı, Türk Tarih Kurumu, Ankara 1997, s. 305-312; A. Süheyl Ünver, “Osmanlı Tababeti ve Tanzimat Hakkında Yeni Notlar”, Tanzimat, MEB, İstanbul 1999, s. 947-959.

2 19. yüzyılın ikinci yarısında Avrupa'da ve Osmanlı'da tahaffuzhanelerin kurumsallaşmasına ilişkin bkz. J. Ferrier, Des Lazarets Des Quarantaines et de la Conférence Internationale pour L'Organisation d'un Service Sanitaire En Orient, Chez Germer Baillière, Paris 1867. Etüve ve pülverizatör makinelerine ilişkin bkz. Devlet-i Aliyye-i Osmaniye Tabaffuzhanelerinde Düstur-ül-amel tutulmak üzere Meclis-i Umur-ı Sibhiye'nin 15 Haziran sene 1315 taribli ictimainda usul-i tebhir hake.enda kararlaşdirlan talimat-i umumiyenin tercümesidir, Matbaa-i Osmaniye, Dersadet 1315/1897, s. 2-3.

3 Bkz. Valeska Huber, "The Unification of the Globe by Disease? The International Sanitary Conferences on Cholera, 1851-1894", The Historical Journal, vol. 49, No. 2, (Jun., 2006), s. 453-476; Norman Howard-Jones, The Scientific Background of the International Sanitary Conferences (1831-1938), Geneva, World Health Organization, 1975; Nermin Ersoy, Yuksel Gungor, Aslihan Akpinar, "International Sanitary Conferences from the Ottoman perspective (1851-1838)", Hygiea Internationalis: An Interdisciplinary Journal for the History of Public Health, sy. 10, 2011, s. 53-79. Osmanlı İmparatorluğu'ndaki karantina uygulamaları Fransa ve İngiltere tarafindan farklı uluslararası politik tartışmalara neden olmuştur. İngiltere'nin Misır ve Osmanlı otoriteleri ile karantina uygulamaları konusunda anlaşmazlıkları için bkz. Sheldon Watts, "Cholera and the maritime environment of Great Britain, India and the Suez Canal: 1866-1883", International Journal of Environmental Studies, sy. 63:1, 2006, s. 19-38. 
"Doğu"da ortaya çıkan salgın hastalıkların Avrupa'ya sirayetinin önlenmesi için Osmanlı Devleti'nden Akdeniz'de, Arap Yarımadası'ndaki limanlar ve özellikle Misır kıyı şeridi ile tüm deniz trafiğinin durdurulmasını böylelikle Akdeniz’in ve Avrupa'nın korunmasını talep etmekteydi. ${ }^{4}$ 19. yüzyıl Osmanlı sıhhiye teşkilatında dört y1l kadar görev alan ve Basra, Klazomen, Kamaran ve Cidde gibi imparatorluğun kilit noktalarında salgın hastalıklar ve alınan önlemlere ilişkin gözlemlerde bulunan Dr. Frederic Borel de Avrupa'da hijyenin sağlanabilmesinin Osmanlı yönetimine bağlı olduğunu belirtmekte ve Osmanlı tahaffuzhanelerinin bir sağlık savunma sistemi oluşturduğunu aktarmaktadır. ${ }^{5}$ Fransa'y1 temsilen uluslararası sağlık konferanslarına katılan Profesör Proust da özellikle Doğu'nun "egzotik" hastalıklarından Avrupa'yı korumanın ancak Süveyş kanalının sık1 kontrolü sayesinde mümkün olabileceğini belirtmektedir. ${ }^{6}$

19. yüzyılda özellikle veba, tifo ve kolera gibi çok sayıda salgın hastalıkla karşı karşıya kalan Osmanlı Devleti, uluslararası karantina uygulamalarını yakından takip etmiştir. Uluslararası Sağlık Konferansı'nın 1866 y1lında İstanbul'da toplanması, Osmanlı yönetiminin konuya verdiği önemi açıkça göstermektedir. ${ }^{7}$ Osmanlı yönetimi, sağlık politikalarının imparatorluk genelinde yaygınlaştırılarak kurumsallaştırılmasını, özellikle uluslararası ticari aktivitenin ve insan trafiğinin

4 Sylvia Chiffoleau, "Les pèlerins, de La Mecque, les germes et la communauté internationale", Médecine/Sciences, sy. 27, 2011, s. 1121-1126; Michael Christopher Low, "Empire and the Hajj: Pilgrims, Plagues, and Pan-Islam Under British Surveillance, 1865-1908”, International Journal of Middle East Studies, sy. 40, 2008, s. 269-290; Peter Baldwin, Contagion and the State in Europe, 1830 1930, Cambridge University Press, Cambridge 2004, s. 229; Alison Bashford, Imperial Hygiene: A Critical History of Colonialism, Nationalism and Public Health, Palgrave Macmillan, New York 2004, s. 117; Gaston Deschamps, Sur Les Routes D'Asie, Armand Colin Et Cie, Paris 1894, s. 114-115.

5 Frederic Borel, Étude d'bygiène Internationale: Choléra et peste dans le Pèlerinage Musulman, 1860-1903, Masson et Cie, Paris 1904, s. i-iii; Gülden Sarıyıldız, Macar Oya, "Cholera Pilgrimage and International Politics of Sanitation: the Quarantine Station on the island of Kamaran" Plague and Contagion in the Islamic Mediterranean, Ed. Nükhet Varlık, Arc Humanities Press, Croydon 2017, s. 243-273. Osmanlı arşiv belgelerinde ve vilayet salnamelerinde, İzmir Urla'da bulunan Klazomen Adası'nda kurulan bu tahaffuzhanenin Klazomen Tahaffuzhanesi olarak adlandırıldı̆̆1 görülmektedir. Metin içinde kısaltılarak kullanılan arşiv kaynaklarının eksiksiz künyelerine kaynaklar kısmında yer verilmiştir. Bedi N. Şehsuvaroğlu, karantina kelimesinin halka yabancı gelmesi nedeniyle karantina anlamında "usul-i tahaffuz", lazaret veya lazarettoya karşılık olarak da "tahaffuzhane" terimlerinin kullanıldığını ve karantina ve karantinahane tabirlerinin ise zaman içerisinde yaygınlık kazandığını belirtmektedir. Bedi N. Şehsuvaroğlu, "Türkiye Karantina Tarihine Giriş I", Istanbul Üniversitesi Tıp Fakültesi Mecmuası, c. 20, sy. 3, 1957, s. 418-444. Klazomen Adası'nın kadim tarihine ilişkin bkz. Aydın Vilâyet Sâlnâmesi, R. 1307/H. 1308, İbrahim Câvid, Türk Tarih Kurumu, Ankara 2010, s. 737-738.

6 A. Proust, La Défense de L'Europe contre Le Choléra, G. Masson, Paris 1892, s. v-vi.

7 Proceedings of the International Sanitary Conference Opened At Constantinople on the 13th February 1866. Bu uluslararası konferansta Osmanlı yönetimi Hac zamanında Hicaz'a bir sağlık komisyonu göndermeyi taahhüt etmektedir. Gülden Sarıyldız, "Karantina", Türkiye Diyanet Vakefi Islam Ansiklopedisi, Cilt 24, İstanbul 2001, s. 465. 
yoğun olduğu liman şehirlerinde karantina ve tahaffuzhaneler inşa edilmesi ile kamu sağlığının (sibhat-i umumiye) korunmasını sağlamaya amaçlamıştır. ${ }^{8}$

19. yüzyılda kullanıma giren buharlı gemiler ve trenlerin etkisiyle ticaret ağlarının kapsamı genişlemiş ve bu genişleme ile birlikte metalar kadar insanın da hareketliliği artmıştır. Bu hareketlilik, vebadan koleraya kadar farklı bulaşıcı hastalıkların etki alanının genişlemesine de neden olmuş ve 19. yüzyılda sahil, gümrük, karantina ve tahaffuzhanelerin güvenliği devletler için ayrı bir önem kazanmıştır. Bu bağlamda, Osmanlı İmparatorluğu'nda 1831 y1lında İstanbul'da ilk karantina inşa edilmiş, 19. yüzyılın özellikle ikinci yarısında salgın hastalıkları önlemek için etüv ve pülverizatörler gibi sterilizasyon ve dezenfeksiyon (tathir ve tebhir) makineleri kullanılmaya başlanmıştır. ${ }^{9}$

19. yüzyılda Osmanlı İmparatorluğu'nda kamu sağlı̆̆ının korunmasında kentleşmenin, belediyelerin kurulmasının ve özellikle bakteriyolojinin gelişimi ile birlikte karantinalar ve tahaffuzhanelerin de büyük rol oynadığ1 görülmektedir. ${ }^{10}$ Osmanlı hıfzıssıhhasının başında bulunan Dr. Kazım İzzeddin'in de belirttiği gibi

81851 yılında Paris’te düzenlenen Uluslararası Sağlık Konferansı'nda Osmanlıların Hijyenistlere karşı Karantinistlerin safında yer aldığı görülmektedir. Karantinistler, şüpheli hastalık taşıdığ1 düşünülen insanların, gemilerin ve eşyaların tecrit edilmesi gerektiğini savunuyorlardı. İngiltere'nin başını çektiği Hijyenstler grubu ise bu uygulamaların uluslararası ticareti sekteye uğrattığını ve bu nedenle karantinadan daha ziyade özellikle hijyene, kamu sağlı̆̆ına ve sterilizasyona ağırlık verilmesi gerektiğini savunmuşlardır. Gülden Sarıyıldız, "Osmanlılarda Hıfzıssıhha”, Türkiye Diyanet Vakefi Islam Ansiklopedisi, Cilt 17, İstanbul 1998, s. 320. Son dönem Osmanlı İmparatorluğu'nda kamu sağlı̆̆ının kurumsallaşmasına ilişkin bkz. İsmail Yaşayanlar, "Osmanlı Devleti’nde Kamu Sağlı̆̆ının Kurumsallaşmasında Koleranın Etkisi”, Osmanlidan Cumburiyet'e Salgın Hastahklar ve Kamu Sağh̆̆g, Ed. Burcu Kurt-İsmail Yaşayanlar, Tarih Vakfi Yurt Yayınları, İstanbul 2017, s. 2-24. Karantina uygulamalarına karşı hareketler için bkz. Christian Promitzer, "Prevention and stigma: the sanitary control of Muslim pilgrims from the Balkans, 1830-1914", Mediterranean Quarantines, 1750-1914: Space, Identity and Power, Ed. John Chircop-Francisco Javier Martinez, Manchester University Press, Manchester, 2018, s. 145-170; Nuran Yildırım, "“Karantina İstemezük" Osmanl Coğrafyasinda Karantina Uygulamalarna İsyanlar”, 14. Yüzynldan Cumburiyet'e Hastalıklar, Hastaneler, Kurumlar: Sağlık Taribi Yą̧ları I, Tarih Vakfi Yurt Yayınları, İstanbul 2014, s. 70-88.

9 Ahmet Midhat Paşa, Osmanlı Devleti'nde karantinaya ilişkin ilk kaydın Takvim-i Vekayinnin 7 Cemaziyelahir 1247 (13 Kasım 1831) tarihli sayısında görüldüğ̈nü ve bu kayda göre Osmanlı’da karantinanın kolera ve tauna (veba) karşı başladı̆̆ını belirtmektedir. Ahmed Midhat, "Devlet-i Aliyye-i Osmaniyye'de Karantina, Yani Usûl-ü Tahaffuzun Tarihçesi”, Salnâme-i Nez̧aret-i Umur-ı Hariciye, 1318 (1902), s. 436-471. Vebanın Osmanlı İmparatorluğu'ndaki seyri için bkz. Daniel Panzac, Osmanl Imparatorluğu'nda Veba (1700-1850), Tarih Vakfi Yurt Yayınları, İstanbul 1997; Mesut Ayar, “1900 İzmir ve 1901 İstanbul Salgınları Bağlamında Vebanın XX. Yüzyıl Başlarında Osmanlı İmparatorluğu'nda Devam Eden Etkisi”, History Studies, 2/2, 2010, s. 173-188.

10 Bkz. Şeref Etker, "Paul-Louis Simond ve Bakteriyolojihane-i Osmani’nin Çemberlitaş’ta Açılışı (21 Eylül 1911)", Osmanl Bilimi Araştırmalar, X/2, 2009, s. 13-33. Etker, kolera araştırmalarının Klazomen Tahaffuzhanesi'ne kadar uzandı̆̆ını belirtmektedir. 
yeni şehir planları ve altyapı çalışmaları hıfzıssıhha pratiklerini de kapsamaktadır. ${ }^{11}$ Osmanlı İmparatorluğu'nda kamu sağlığının korunması ve karantinalar ile tahaffuzhanelerin teşkili ağırlıklı olarak 19. yüzyılın ikinci yarısında düzenlenen nizamnameler ve talimatnameler ile hukuki açıdan yapılandırılmıştır. ${ }^{12}$ İmparatorluk limanlarına yanaşan gemiler, mürettebatı ve yolcuları ile birlikte dikkatli bir şekilde incelenmiş ve yolcuların eşyaları dezenfekte edilmiştir. İzmir, Selanik ve Beyrut 19. yüzyıl deniz ticaretinin en aktif olduğu liman şehirleri arasında olduğu için ilk karantina istasyonları bu şehirlerde kurulmuş, salg1n hastalıklara karşı modern cihazlar yine ilk kez bu şehirlerin karantina ve tahaffuzhanelerinde kullanıma sunulmuştur. ${ }^{13}$ İzmir, İstanbul'dan sonra profesyonel karantina organizasyonunun kurulduğu ilk şehirdir. ${ }^{14}$ İstanbul'daki Kavak Tahaffuzhanesi'nden sonra Urla'da Klazomen Adası'nda inşa edilen Klazomen Tahaffuzhanesi, 110 derece buhar gücü ile yolcuların eşyalarını "tazyik-i buhar ile tathir ve tebhir" yani buhar gücü ile dezenfeksiyon işlemini gerçekleştirebilen Fransız Geneste-Herscher marka etüv makinelerinin ilk kez kullanıldığ1 yerlerden biridir. ${ }^{15}$ Hem Beyrut hem Klazomen

11 Birsen Bulmuş, Plague, Quarantines and Geopolitics in the Ottoman Empire, Edinburgh University Press, Edinburgh 2012, s. 5.

12 Bedi N. Şehsuvaroğlu, 1867'de Meclis-i Tahaffuz tarafindan kaleme alınan Kolera Nizamnamesi’nin 19. yüzyıl sonlarına dek yürürlükte kaldığını belirtmektedir. Şehsuvaroğlu, a.g.m., s. 430. Bedi N. Şehsuvaroğlu, Türkiye Karantina Teşkilatını İdare Edenler altbaşlığı ile 19. yüzyıldan 1920lere dek karantina teşkilatının kimler tarafindan idare edildiğini detaylı olarak incelemektedir. Bedi N. Şehsuvaroğlu, "Türkiye Karantina Tarihine Giriş III”, İstanbul Üniversitesi T⿰р口十 Fakültesi Mecmuasi, Cilt 21, sy. 1, 1958, s. 146-169. "Asitane-i Âliyye'de tahaffuzhanenin inşasına kadar boğaz-1 bahr-1 sefid'de ittihaz olunan karantina'da sefain-i Osmaniye ve ecnebiyenin tabi oldukları şeraite dair talimat", Salname-i Hariciye, Sene 1318 (1900), s. 439; "ilk Defa olarak Anadolu canibinde İttihaz Olunan Karantina Kordonuna Dair Fermanı Hümayun", Evahir-i Safer 1254 (1838), Salname-i Hariciye, Sene 1318 (1900), s. 442; "Karantina memurlarının keyfiyet-i memuriyetleriyle haklarında defterdardan ve mal müdür ve memurları taraflarından olunacak muamelata dair talimat", 15 Muharrem 1267 (20 Kasım 1850); "Karantina rüsumu tarifesi”, 3 Zilhicce 1272 (5 Ağustos 1856), Salname-i Hariciye, s. 664; Babriye-i Ticariye Salnamesi, 1329 (1913), s. 82-83; Rapport de la Commission Chargée Par Le Conseil de Santé d'Élaborer un Projet de Tarif des Droits Sanitaires dans L'Empire Ottoman, Imperimerie Centrale, Constantinople 1866, s. 5.

13 Gülay Tulasoğlu, ““'Humble Efforts in Search of Reform”: Consuls, Pashas, and Quarantine in Early-Tanzimat Salonica", Well-Connected Domains: Towards an Entangled Ottoman History, Ed. Pascal W. Firges vd., Brill, Leiden 2014, s. 188-207.

14 Pelin Böke, "İzmir Karantina Teşkilatının Kuruluşu ve Faaliyetleri (1840-1900)", CTTAD, VIII/18-19, s. 140; Léon Kontente, Smyrne et l'Occident, Yvelinéedition, Montigny-le-Bretonneux 2005, s. 522-523.

15 Bkz. Nuran Yıldırım, "Tersane-i Amire Fabrikaları'nda Tebhir Makinas1/Etüv Üretimi ve Kullanımı", Dünӥ ve Bugünü ile Halic Semposyumu Bildirileri, 22-23 Mayıs 2003, Ed. Süleyman Faruk Göncüoğlu, Kadir Has Üniversitesi Yayınları, İstanbul 2004, s. 421-429; Nuran Yıldırım, "Disinfecting Stations in Ottoman Empire", Science in Islamic Civilisation: Proceedings of the International Symposia, Science Institutions in Islamic Civilisation and Science and Technology in the Turkish and Islamic World, Ed. Ekmeleddin İhsanoğlu-Feza Günergun, IRCICA, İstanbul 
Tahaffuzhanesi için Marsilya'dan etüv makinesi ve dezenfeksiyon için gerekli ilaçlar getirilmiş, Akdeniz karantina ağının bir parçası olan Klazomen Tahaffuzhanesi, salgın hastalıklara karşı izolasyon, dezenfeksiyon ve sterilizasyon görevlerini ifa etmiştir. ${ }^{16}$

Bu makale, ağırlıklı olarak Osmanlı Arşivi’ndeki belge koleksiyonlarına ve 19. yüzyılda Osmanlıca ve Fransızca yayımlanan karantina ve kamu sağlığ1 literatürüne dayanarak Klazomen (Urla) Tahaffuzhanesi’nin kuruluşunu ve son dönem Osmanlı İmparatorluğu'ndaki karantina uygulamalarını uluslararası karantina uygulamaları ve kamu sağlı̆̆1 perspektifinden incelemektedir. Makalenin ilk bölümünde Klazomen Tahaffuzhanesi’nin yapılandırılması ve kamu sağlığının temini açısından oynadı̆̆ kritik rol, ikinci bölümünde ise tahaffuzhanenin Akdeniz karantina ağı ile olan ilişkisi ele alınmaktadır.

\section{Klazomen Tahaffuzhanesi'nin Kuruluşu ve Yapılandırılması}

Osmanlı İmparatorluğu'nun önemli liman şehirlerinden biri olan İzmir'de, 1868 yılında belediyenin kurulması ile birlikte su, kanalizasyon, kaldırım ve aydınlatma gibi altyapı çalışmaları gerçekleştirilmiştir. ${ }^{17}$ İzmir'de limanın, Kordon'un ve demiryollarının inşa edilmesi ile birlikte şehrin ekonomik faaliyetleri de hız kazanmıştır. ${ }^{18}$ İzmir'in ilk karantinası, kente oldukça yakın bulunan bir noktada 1846 y1lında inşa edilmiş olsa da bu karantina, 1848 yılında bir yangınla yok olmuştur. ${ }^{19}$ Karantina, 1866-1869 y1lları arasında Urla'daki Klazomen Adası'na taşınmıştır. ${ }^{20}$ İzmir'de 1865 yılında yaşanan ve kentte yıkıcı etkiler bırakan kolera salgını bu taşınma sürecini hızlandırmıştır. ${ }^{21}$ Tahaffuzhanenin 14.000 liradan daha az bir miktara inşa edilmesi planlanmıştır. ${ }^{22} 1879$ yılı Aydın Vilayet Sâlnâmesi,

2000, s. 267-277; Besim Ömer, Akil Muhtar, Koleraya Karșı İttibazı Lažm Gelen Tedâbir ve Etıbbaya Rehber, Arşak Garviyan Matbaası, İstanbul 1328 (1910), s. 153-162.

16 BOA, A.MKT.MHM: 571/10 (7 Temmuz 1310/19 Temmuz 1894). Akdeniz karantina ağına ilişkin bkz. Mediterranean Quarantines, 1750-1914: Space, Identity and Power, Ed. John ChircopFrancisco Javier Martinez, Manchester University Press, Manchester 2018.

17 İzmir Şebir Rebberi, 1941, Ed. Suad Yurdkoru, İzmir Belediyesi Neşriyatı, İzmir 1941, s. 182-194; Rauf Beyru, 19. Yüzynlda İzmir Kenti, Literatür, İstanbul 2011, s. 319-335; Erkan Serçe, Tanz̨imat'tan Cumburiyet'e İmir'de Belediye (1868-1945), Dokuz Eylül Yayınlar1, İzmir 1998, s. 54.

18 Elena Frangakis-Syrett, "The making of an Ottoman port: The quay of Izmir in the nineteenth century", The Journal of Transport History, 22/1, 2001, s. 23-46.

19 Böke, a.g.m., s. 142.

20 Sibel Zandi Sayek, Ottoman Irmir: The Rise of a Cosmopolitan Port (1840-1880), University of Minnesota Press, London 2012, s. 84; Rauf Beyru, 19. Yüsyllda İzmir'de Sağhlk. Sorunlar ve Yaşam, İBB Kent Kitaplığı, İzmir 2005, s. 101-103.

21 İzmir'de 1865 yllında etkili olan koleraya ilişkin olarak "İzmir'in sthhi topografyasını" inceleyen Dr. Chasseaud’un raporlarına ilişkin bkz. Özgür Yılmaz, "İzmir'in Salgın Hastalıklar Tarihine Bir Katkı: Avrupalı Hekimlerin Gözüyle 1865 Kolera Salgını", Tarih ve Günce: Atatürk ve Türkije Cumburiyeti Taribi Dergisi, sy. 8, 2021 Kış, s. 85-128.

22 BOA, ML.EEM: 24/15 (27 Teşrin-i sani 1328/9 Aralık 1872). 
Klazomen Tahaffuzhanesi'nin işlevini “İzmir'e vürûd edecek olan vapur ve sefâin ile yolcular lede'l-icâb orada karantina müddetini ikmal ederler" ifadesi ile tespit etmektedir. ${ }^{23}$ Klazomen Tahaffuzhanesi'nin Izmir'e yakın bir mesafede bulunan Urla'da ve bir ada üzerinde kurulmuş olması elbette tesadüfi değildir. Polonya'daki Holm Tahaffuzhanesi, Fas'taki Mogador Adası ve Venedik'teki Lazaretto Nuovo gibi bulaşıcı hastalık taşıyanlar ya da taşıma şüphesi olanlar ile kent sakinlerini ayrılarak gerekli sıhhi işlemlerin yapılması 19. yüzyılın ikinci yarısında yaygin bir uygulamayd.

1891 y1lında Saray-1 Hümayun kimyageri ve Hıfzıssıhha-i Umumiye Müfettişi Bonkowski Paşa, Meclis-i Vâlâ’ya sunduğu arîzasında, Kamran, Ebu Said, Trablusgarp, Beyrut, Klazomen ve Çanakkale'de "Avrupakâr" tahaffuzhanelerin inşa edilmesinin gerekli olduğunu işaret etmiş ve tüm bu inşaatların yüzbin lira masrafla gerçekleşebileceğini aktarmıştır. Meclis-i Vâlâ, bu tahmini inşaat masrafinın çok yüksek olduğunu ancak 5-6.000 lira masraf ile gerekli karantina mahallerinin oluşturulabileceğine kanaat getirmiştir. Meclis, kolera hastalı̆̆ının Osmanlı belgelerinin dili ile "bulaşık mahaller"den yani bulaşıcı hastalık taşıdığı düşünülen yerlerden gelenlerin eşyaları ve elbiseleri ile taşındı̆̆ına vurgu yaparak hastalığ1 önlemek için Fransa tahaffuzhanelerinde olduğu gibi "bir alet-i mabsusa" yani etüv makinesi ile tahaffuzhanedekilerin eşyalarının ve elbiselerinin dezenfekte edilmesini ve bu makinelerden ihtiyaç duyulan miktarda satın alınmasını talep etmiştir. ${ }^{24}$ Bonkowski Paşa, uluslararası sağlık konferanslarında sıklıkla dile getirilen koleranın her sene ortaya çıkmasının ardında yatan temel nedenin Hindistan'dan gelen hacılar olduğu argümanını yineleyerek Kamran adasında inşa edilmiş olan tahaffuzhanenin bir dereceye kadar hastalığın yayılmasını önlediğini ancak özellikle hacı nüfusunun artması ile birlikte gerekli sağlık koşullarının sağlanamadığını aktarmaktadır. Bonkowski Paşa’ya göre, tam da bu nedenle, Kavak, Beyrut ve Basra tahaffuzhanelerinin yenilenmesi gerekmekteydi. ${ }^{25}$

1893 yılında İzmir ve civarında koleraya karşı alınan tedbirleri incelemek üzere Aydın Vilayeti'ne gönderilen Bonkowski Paşa, İzmir hapishanesini ziyaret etmiş, bulaşıcı hastalıklara karşı hapishanede alınan önlemleri takdirle karşılamıştır. Bonkowski Paşa, Klazomen Tahaffuzhanesi'ni de ziyaret etmiş, karantinada sadece bir vebalı hasta olduğunu belirterek karantina personeline padişahın ihsanı olarak et, helva ve pilavdan oluşan bir ziyafet vermiştir. ${ }^{26}$ Bonkowski Paşa, payitahta gönderdiği raporunda Klazomen Tahaffuzhanesi’nin gerek fiziksel gerek hijyen bakımından yetersiz olduğunu belirtmiştir. ${ }^{27}$ Tahaffuzhanedeki su kanallarının kırık

\footnotetext{
23 Aydın Vilayet Sâlnâmesi, 1296 (1879), s. 91.

24 BOA, MV: 66/72 (4 Muharrem 1309/10 Ağustos 1891).

25 BOA, MV: 66/72, (4 Muharrem 1309/10 Ağustos 1891).

26 BOA, Y.PRK.SGE: 6/2 (23 Eylül 1309/5 Ekim 1893).

27 BOA, A.MKT.MHM: 562/30 (29.04.1311/9 October 1893).
} 
olması, mikropların bu tahaffuzhanede çalısanlara ve dezenfeksiyon için bekleyenlere bulaşabileceğini göstermektedir. Bonkowski Paşa, Klazomen Tahaffuhanesi'nin hem payitahtın hem de İzmir art bölgesinin salgin hastalıklardan korunması için en önemli noktalarından biri olduğunu belirterek bu tahaffuzhanenin gerekli sağlık ve dezenfeksiyon şartlarını karşılamadığını aktarmaktadır. Bonkowski Paşa, tahaffuzhane yetkililerinin henüz etüv makinesi ile dezenfekte edilmeyen bulaşık eşyalar ile karantina bekleyenlerin fiziksel olarak ayrı yerlerde tutulması gerektiğine de dikkat çekmiştir. Bonkowski Paşa, 1893 yllında Avusturya hükümetinin izniyle Avusturya'dan bir bakteriyoloji uzmanının Klazomen Tahaffuzhanesi'ne davet edilerek karantinadaki hastaların özellikle hacıların incelendiğini ve hastalığa yol açan mikrobun ne olduğu konusunda incelemelerde bulunulduğunu Sihhiye Nezareti'ne bildirmiştir. ${ }^{28}$

Klazomen tahaffuzhanesinin en önemli sorunlarından biri kapasite sorunuydu. Osmanl belgeleri, Klazomen Tahaffuzhanesi'nin kapasitesine ilişkin olarak bize 19. yüzyılın sonlarında tahaffuzhanenin beş yüz ila bin sekiz yüz kişiyi istiap edebilecek kapasitede olduğunu göstermektedir. ${ }^{29}$ 20. yüzyıl başlarında tahaffuzhanenin iki bin kişilik bir kapasiteye ulaşttğı anlaşılmaktadır. ${ }^{30}$ Osmanlı yönetimi, özellikle hac zamanında bu kapasite sorununu çözmeye çalısmış ise de bütçe sıkıntıları nedeniyle çoğu zaman tahaffuzhaneye ek yeni binaların inşası yerine çadır ve barakalar ile geçici çözümleri uygulamaya koymuşlardır. ${ }^{31}$ Klazomen Tahaffuzhanesi zaman içerisinde kurumun ihtiyaçlarına yönelik olarak çeşitli tadilatlardan geçirilmiştir. ${ }^{32}$ Klazomen Tahaffuzhanesi’nin 19. yüzyıl sonlarına ait mimari planını (bkz. Resim 1) incelediğimizde karantinaya alınacak yolcuların

28 BOA, BEO: 255/19054 (30 Temmuz 1309/11 Ağustos 1893). 1893 yllında İzmir Karantina İdaresi'nin Hizmet gazetesine ilettiği bir varaka ile Trablusgarp taraflarından gelenlerin Klazomen ve Beyrut tahaffuzhanelerinden birinde on gün karantinaya vaz' edilmesi gerektiğ, Venedik körfezi üzerinde kain Avusturya ve Macaristan sahillerinden gelenler hakkında uygulanan yirmi dört saat ihtiyat karantinasının ise lağvedildiği ancak gelenlerin tabip kontrolünden geçirilmesi gerektiği bildirilmiştir. Hiæ̌met, 2 Aralık 1893, s. 1.

29 BOA, BEO: 227/16982, (14 Haziran 1309/26 Haziran 1893); BOA, A.MKT.MHM: 578/8, (23.12.1316/4 May 1899). 1892 yllinda inşa edilen Sinop tahaffuzhanesi ise 300 kişilik olarak tasarlanmış ancak daha sonra genişletilmiştir. Erol Karc1, "Kolera ile Mücadelede Örnek Bir Sağlık Müessesesi: Sinop Tahaffuzhanesi ve Faaliyetleri (1892-1908), XVII. Türk Tarih Kongresi, Ankara: 15-17 Eylül 2014, Kongreye Sunulan Bildiriler, IV. Cilt - V. Kısım Osmanl Taribi, Ankara, Türk Tarih Kurumu, 2018, s. 1880-1881.

30 BOA, BEO: 3194/239543 (20 Şevval 1325/26 Kasım 1907).

31 BOA, A.MKT.MHM: 576/20 (21.01.1316/11 Haziran 1898).

32 19. yüzyılın sonlarında Avrupa'nın koleraya karşı savunması üzerine bir kitap kaleme alan Proust, Klazomen tahaffuzhanesinin Osmanlı tahaffuzhaneleri içerisinde yolcuların uygun bir şekilde barındırılması için gayet iyi durumda olduğunu ancak tahaffuzhanenin bir miktar tadilata ihtiyacı olduğunu belirtmektedir. Proust, a.g.e., s. 376. 
kalacağı odalar, tahaffuzhanenin korunması ile görevli jandarmalar için barakalar ve tahaffuzhane personelinin kalacağı yapıların olduğu görülmektedir. ${ }^{33}$

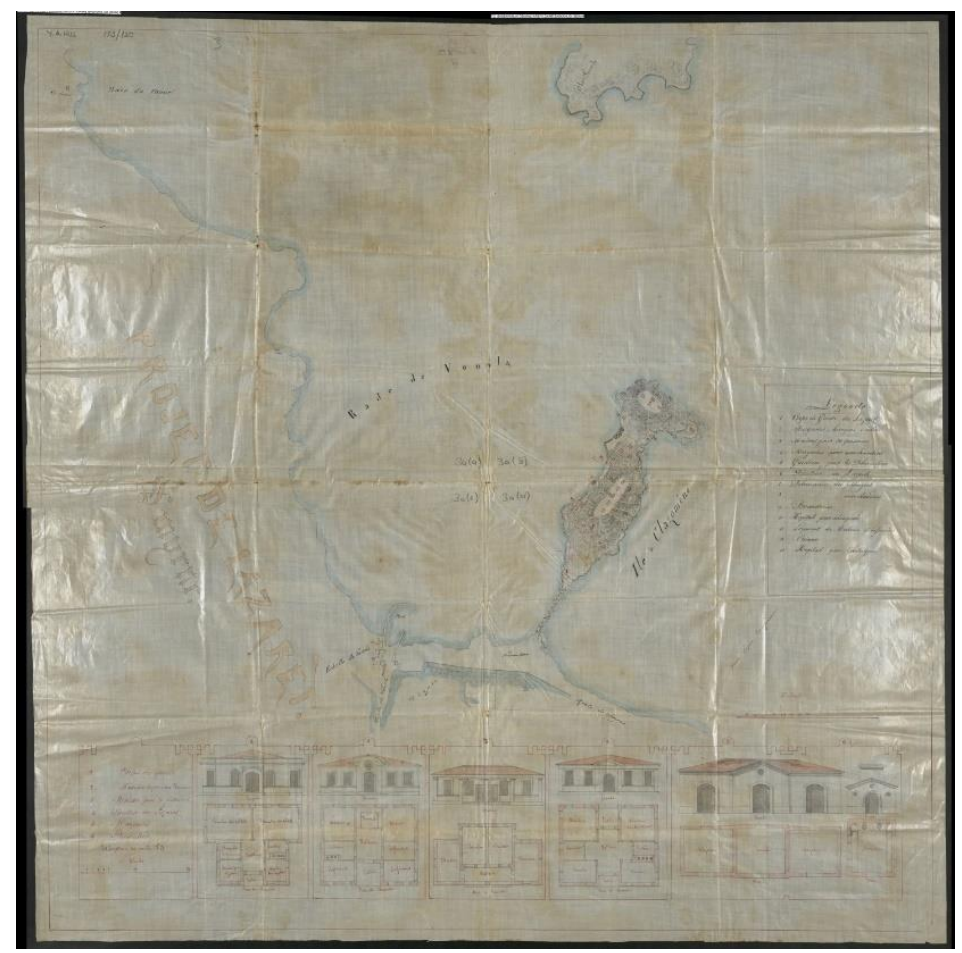

Resim 1: Klazomen Tahaffuzhanesi'nin Planı (Projet De Lazaret Smyrne). ${ }^{34}$

Arşiv kaynakları, tahaffuzhane personeline ilişkin detaylı bilgiler sunmamaktadır. Osmanlı tahaffuzhanelerindeki personel genellikle müdür, tabip, ser nigâhbân, gardiyan, kâtip ve tebhir makinistinden oluşmaktadır. ${ }^{35} 20$. yüzyılın başlanında kaleme alınan Osmanlı müfettiş ve mühendislerinin raporlanna göre,

33 BOA, Y.A.HUS: 173/120 (15.08.1300/21 Haziran 1883). Umum Erkan-1 Harbiye Dairesi, hapishane-i umumiyi ve birçok karakolu korumakla görevli olan askerlerin sayıca az olması nedeniyle tahaffuzhanenin jandarma tarafindan muhafaza edileceğini belirtmektedir. BOA, A.MKT.MHM: 566/14 (2 Kanun-1 evvel 1310/14 Aralık 1894). Urla Tahaffuzhanesi'nin mimari yapısına ilisskin olarak bkz. Ebru Yılmaz, "A Discussion on the Spatial Representation of the Ottoman Modernization: Urla Quarantine Building", Online Journal of Art and Design, volume 8, issue 4, October 2020, s. 1-24; Gonca Z. Tuncbilek, "Quarantine (d) Space: Urla-Izmir (Smyrna) Island, Space and Culture, Vol. 23 (3), 2020, s. 246-252.

34 BOA, Y.A.HUS: 173/120.

35 Beyru, 19. Yürynlda İzmir'de Sağhlk Sorunlar ve Yaşam, s. 119; Kâmil Şahin, "XIX. Yüzyll Sonlarında Kastamonu'da Hastahaneler”, İkinci Kastamonu Kültür Semposyumu Bildirileri (18-20 Eylül 2003), Kastamonu Valiliği, Ankara 2005, s. 124. 
Tahaffuzhane'nin bazı bölümlerinin tamiri hatta yeniden inşa edilmesi gerekmekteydi. ${ }^{36} 1905$ yilında kolera hastalarına özel bir hastahane, doktorlar ve gardiyanlar için odalar, bir çamaşırhane, tebhirhane ve hamamlar yeniden inşa edilerek tahaffuzhane yenilenmiştir. ${ }^{37} 1907$ yllinda karantina bekleyecek yolcular için yeni bir parlatorya dairesinin (bkz. Resim 2) yapımı planlanmıştır. ${ }^{38}$ Parlatorya dairesinde kabul salonu, mükaleme mahalli, divanhane, posta ve telgraf dezenfeksiyon mahalli ve nekahet odası bulunmaktaydı.

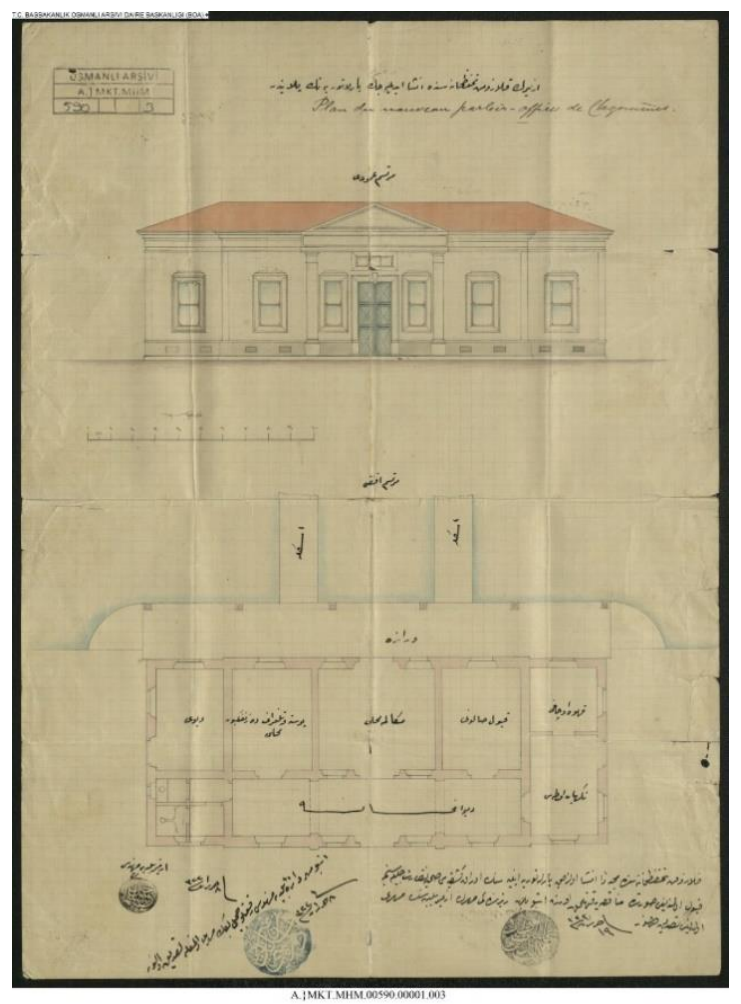

Resim 2: "İzmir Klazomen Tahaffuzhanesinde İnşa Edilecek Parlatoryanın Planıdır”39

36 BOA, A.MKT.MHM: 582/15 (21.12.1319/31 Mart 1902); BOA, A.MKT.MHM: 588/17 (10.3.1323/15 Mayıs 1905); BOA, A.MKT.MHM: 590/1 (4.7.1324/24 Ağustos 1906).

37 BOA, A.MKT.MHM: 588/17 (12 Cemaziyelahir 1323/14 Ağustos 1905).

38 BOA, BEO: 3205/240356 (22 Ramazan 1325/29 Ekim 1907). 751, dn. 54: "Karantinahâne önüne inşâ edilen parlatorya, bir iskeledir. Bu iskelede sadece karantina memurları ve gardiyanlar bulunur. Gemilerin patentelerinin (sıbbiye tę̧kiresi) vizelenmesi ve karantina istintak işlemleri için parlatorya kullanılır.", İsmail Yaşayanlar, "Osmanlı Döneminde Uygulanan Deniz Karantinasına İlişkin Bazı Bilgiler”, Âb-ı Hayât’ Aramak: Gönül Tekin'e Armağan, Ed. Ozan Kolbaş-Orçun Üçer, Yeditepe, İstanbul 2018, s. 737-761.

39 BOA., A.MKT.MHM: 590/1. 


\section{Hac Trafiğinde Klazomen Tahaffuzhanesi'nin Yeri}

16. yüzyıldan itibaren Mekke ve Medine'nin koruyucusu unvanını taşıyan Osmanlı sultanları için Hac güvenliğinin sağlanması ve Dünya'nın hemen her yerinden hac farizasını yerine getirmek için kutsal topraklara giden Müslümanların korunması tarihi ve sembolik bir öneme haizdi. ${ }^{40}$ Uluslararası Sağlik Konferansları'nın en önemli gündem maddelerinden biri bu hareketliliğin salgın hastalıkların kapsamını genişletmesi ve hastalıkların Avrupa'ya yayılmasıydı. ${ }^{41} \mathrm{Bu}$ bağlamda, hac trafiği Osmanlılar tarafından yakından takip edilmiş, 19. yüzyılda Osmanlı Devleti'nde yaygınlaşmaya başlayan karantina ve tahaffuzhane uygulamaları ile birlikte bulaşıcı hastalıkların yayılması önlenmeye çalışılmıştır. ${ }^{42}$ Payitaht, Hac zamanında İstanbul'daki bazı doktorları hacıların sağlığının korunması için Hicaz'a görevli olarak göndermiştir. ${ }^{43}$ Sağlık müfettişi Koçoni Efendi de bu doğrultuda Klazomen Tahaffuzhanesi'ne gönderilmiș, tahaffuzhanenin 1slah edilmesine, tahaffuzhanede kolera hastaları için ayrı bir hastahane inşa edilmesine ve "büccacın temin-i istirahatleri esbabına" ilişkin görevlerde bulunmuştur. ${ }^{44}$

1890 yılında Hicaz'daki kolera salgınının imparatorluğun diğer bölgelerine yayılmasını önlemek için Sihhiye Nezareti bir dizi önlem almıştır. Elbette bu önlemlerin en başında "bulaşık mahaller"den gelenlerin karantinahanelere gönderilerek layıkıyla muayene edilmesi ve sağlık durumlarına göre gereken karantina usulünün uygulanması gelmekteydi. Hacca giden ve Hac'dan dönen binlerce hac1, Klazomen Tahaffuzhanesi'nde sağlik kontrolünden geçiriliyor, eşyaları dezenfekte ediliyor, hasta olanlar ise tedavi altına alınıyordu. 1890 yılında yaklaşık üçbinbeşyüz hacıyı taşıyan Osmanlı vapurları Süveyş Kanalı'ndan geçerek karantina işlemleri için Beyrut ya da İzmir'e varmışlardı. Sıhhiye Nazırı'nın detaylarını Dahiliye Nezareti'ne aktardığı üzere hem İzmir'de hem de Beyrut'ta tecrübeli müdürler, sağlık müfettişleri ve sağlık memurları hazır bulunmaktaydı. Hicazdan dönen hacıları taşıyan vapurlar çoğunlukla Trablusgarp ya da Klazomen tahaffuzhanelerine sevk ediliyor, bu tahaffuzhanelerde "usul-i fenniyeye" uygun bir şekilde eşyaları ve elbiselerinin tamamı dışarı çıkarılarak tebhir ve tathir ediliyordu. ${ }^{45}$

40 Derya Geçili, "Osmanlı Devleti'nde Hacıların Gemilerle Nakledilmesi Sırasında Alınan Önlemler”, Tarib Okulu Dergisi, Haziran 2017, sy. XXX, s. 61-83.

41 Bkz. Güner Doğan, "Osmanlı İmparatorluğu’nda Karantina Uygulaması ve Venedik Uluslararası Sıhhiye Konferansı”, Hacettepe Üniversitesi Türkiyat Araştırmalar Dergisi, sy. 15, Güz 2011, s. 91-109. Kolera, veba ve humma gibi salgın hastalıklar ortaya çıtıı̆ı̆nda devletlerin alacağı önlemlere, etüv makinesi ile tebhirat işlemlerine ve limanlarda alınacak tedbirlere dair bkz. 1912 Beynelmilel Paris Mukavele-i Sibhiyesi, Kader Matbaasi, Dersaadet 1339 (1920).

42 Bkz. Gülden Sarıyldız, Hicaz Karantina Teşkilâtı (1865-1914), Türk Tarih Kurumu, Ankara 1996.

43 BOA, A.MKT.MHM: 572/23 (25 Teşrin-i sani 1311/7 Aralık 1895).

44 BOA, A.MKT.MHM: 582/15 (21.12.1319/31 Mart 1902).

45 BOA, A.MKT.MHM: 576/17 (4 Haziran 1314/16 Haziran 1898). 
Hacilar bu karantinalardaki kontrolleri ve tedavileri bittikten sonra Bahr-i Sefid Boğazı'nda ve Haliç'te hekimler tarafından yeniden kontrol ediliyorlardı. ${ }^{46}$ Uzun karantina prosedürlerine takilmadan memleketlerine dönmek isteyenler Ecnebi posta vapurlarına biniyorlardı ancak Osmanlı bandıralı hacıları taşıyan vapurlara Klazomen Tahaffuzhanesi'nde karantina beklettirilirken Ecnebi posta vapurlarıyla dönen hacıların karantinaya alınmamaları Sıhhiye Nezareti'nin dikkatini çekmiş ve gerekli sağlık tedbirlerinin alınması için "bangi bir devlet sancağ̀ bamil olur ise olsun" Osmanlı limanlarına gelen tüm vapurlara aynı muamelenin yapılması gerektiği belirtilmiştir. ${ }^{47}$

1890 yilinda, Klazomen Tahaffuzhanesi'nde Anadolu'dan gelen hacilar ile Fransa tebaasından olduğu anlaşılan Afrikalı hacılar arasında kavga çıkmıştır. Detaylarını arşiv belgelerinden takip edemediğimiz bu kavgada, Anadolu'dan gelen yaşlı bir hacı kavga sırasında üzerine düşenlerden biri nedeniyle ölmüş, bir hacı da yaralanmıştır. ${ }^{48}$ Öte yandan, Hiæmet gazetesi Urla tahaffuzhanesinde bulundukları müddet zarfında kendilerine gösterilen "muamele-i insaniye"den dolay1 haciların tahaffuzhane yetkililerine şükranlarını sunduğunu bildirmektedir. ${ }^{49} 1895$ yılında Sihhiye Nazırı, Tur-1 Sina Tahaffuzhanesi'nde karantina bekledikten sonra Osmanlı iskelelerine gelen hacıların ne kadar süre ile karantinada tutulmaları gerektiği konusunun Meclis-i Sihhiye'de tartışıldı̆̆ını belirtmektedir. Tur-1 Sina'da hacıların yatak ve yorganları dahil olmak üzere hemen hiçbir eşyasının tebhir edilmemesinden şikâyet eden Sihhiye Nazırı, hacıların Trablusgarp, Beyrut ve Klazomen tahaffuzhanelerine ulaştığında üç gün karantinada tutulmaları ve bu süre zarfinda tathir ve tebhir işlemlerinin gerçekleştirilmesi gerektiğini vurgulamıştır. $\mathrm{Bu}$ işlemler bitmeden hacıların yollarına devam etmesine kesinlikle izin verilmemesi gerektiğini de belirtmiştir. ${ }^{50}$

Hac zamanında birbiri ardına Urla’ya yanaşan vapurlardan karantinaya alınan binlerce hacı için Klazomen Tahaffuzhanesi'nin kapasitesi yeterli değildi. S1hhiye Nazırı Koçoni Efendi, 1898 yılı Haziranı'nda yaşanan izdiham nedeniyle Klazomen Tahaffuzhanesi'nde hacılar için barakaların inşa edilmesi ya da çadırların hazırlanması gerektiğini belirtmiştir. ${ }^{51} 1898$ y1lında, Tur-1 Sina'ya gelen altı yedi bin hacıdan her gün yüz kadarının karaya çıkarılarak bulaşıcı hastalık taşıyıp taşımadıklarına bakılması neticesinde vapurlarda günlerce bekleyen hacılar, S1hhiye Nezareti'ne karantina müddetlerini Klazomen Tahaffuzhanesi'nde tamamlamaları

46 BOA, DH.MKT: 1755/95 (11 Muharrem 1308/27 Ağustos 1890).

47 BOA, BEO: 45/3352 (13 Muharrem 1310/7 Ağustos 1892); BOA, İ.HUS: $1 / 19$ (25 Temmuz 1308/6 Ağustos 1892); BOA, Y.A.HUS: 263/59 (15 Muharrem 1310/9 Ağustos 1892).

48 BOA, DH.MKT: 1771/90 (3 Teşrin-i sani 1306/15 Kasım 1890).

49 Hizmet, 2 Kasım 1890, s. 1.

50 BOA, A.MKT.MHM: 572/13 (20 Haziran 1311/2 Temmuz 1895).

51 BOA, A.MKT.MHM: 576/22 (30 Mayıs 1314/11 Haziran 1898); BOA, A.MKT.MHM: 578/8 (22 Nisan 1315/4 May1s 1899). 
ve Mısır'daki sıhhiye meclisince alınan karantinanın kaldırılması taleplerini bildiren bir telgraf göndermişlerdir. Koçoni Efendi, Cidde'nin veba hastalığından dolayı "dâiren-mâdâr" olduğunu yani kordon (cordon sanitaire) altında bulunduğunu ve bu kordonun kaldırılması halinde hastalığın yayılarak hacıların daha zor şartlarda kalacağını ve bu nedenle sıhhi prosedürlere usulünce uyulmasinın zorunlu olduğunu aktarmaktadır. ${ }^{2} 1902$ yılında hacıların Tur-1 Sina karantinalarında kaldıktan sonra Trablusgarp, Beyrut ve Klazomen tahaffuzhanelerinin birinde beş gün daha karantinada bekletildikleri ve hac kafileleri arasinda hasta olan var ise tamamen iyileşinceye kadar tahaffuzhane hastanelerinde tedavi edilmeleri gerektiği Sadaret'ten Dahiliye Nezareti'ne bildirilmiştir. ${ }^{53}$ Klazomen Tahaffuzhanesi'nde karantina sırasında vefat eden hacıların eşyaları ve paraları Karantina İnspektörlüğü ile Vilayet Polis İdaresi aracılığı ile müteveffaların varislerine gönderiliyordu. ${ }^{54}$

Hac zamaninda Rusya sahillerinden Sinop tahaffuzhanesine gelen ve Rusya Müslümanlarını taşıyan vapurlardan bazıları da Sinop tahaffuzhanesinin istiap haddinin oldukça üzerinde olması nedeniyle doğrudan "her bir levâzımı mükemmel" olan Klazomen Tahaffuzhanesi'ne yönlendirilmekteydi. 55 Sinop'tan Klazomen'e yönlendirilen ve karantinaya alınan vapurlarda yapılan incelemeler sırasinda şüpheli hastalığın yanı sıra "süpheli”, "müfsid” ve “anarşist” olarak tanımlanan kişiler de tespit edilmekteydi. Örneğin, 1907 yilında, Sinop’tan Klazomen Tahaffuzhanesi’ne yönlendirilen vapurlardan birinde gerçek ismi Nikola Vilediviç olan bir kişi İzmir Rus konsolosu aracılığıyla üzerinde sahte pasaportlarla yakalanmıştır. Aydın Valisi Faik Bey, Zabtiye Nezareti'ne gönderdiği telgrafta bu kişinin Beyrut, Yafa ve Şam taraflarına giderek bu şehirlerdeki Rus konsoloslarından zorla para aldığını ve Rusya'da bulunduğu sırada çete kurarak bankaları soyduğunu ve bazı kişileri katlettiğini aktarmaktadır. Vali, Nikola Vilediviç'in yakalandığı sırada üzerinde Rus askeri mülazımlarının üniforması olduğunu ve eşyaları arasında Rus konsoloslarının resmi mühürlerine benzer hurufatlar, çok sayıda evrak, mürekkep ve boya bulunduğunu belirtmekte tüm bunların İzmir Rus konsolosu tarafindan müsadere edildiğini de aktarmaktadır. Nikola Vilediviç, Rusya kumpanyasının Lazerof vapuruyla Midilli, Kale-i Sultaniye ve Dersaadet yolu ile Odessa'ya gönderilmiştir. ${ }^{56}$

52 BOA, Y.A.HUS: 384/104 (7 May1s 1314/19 May1s 1898).

53 BOA, DH.MKT: 501/73 (17 Nisan 1318/30 Nisan 1902).

54 BOA, HR.UHM: 118/35 (25 Kanun-1 sani 1327/7 Şubat 1912).

55 BOA, BEO: 3194/239543 (20 Şevval 1325/26 Kasım 1907); BOA, BEO: 3202/240106 (21 Teşrin-i sani 1323/4 Aralık 1907); BOA, BEO: 3207/240495 (19 Teşrin-i sani 1323/2 Aralık 1907); BOA, İ.HUS: 160/101 (28 Şevval 1325/4 Aralık 1907). Rusya Müslümanlarının hac yoluna ilişkin olarak bkz. İsmail Yaşayanlar, "Hicaz Yolunda Kolera: Rusya Müslümanlarının Kullandığı Karadeniz Hac Yolu ve Koleranın Yayllımına Etkisi”, Avrasya Incelemeleri Dergisi-Journal of Eurasian Studies, IV/2, 2015, s. 178-203.

56 BOA, BEO: 3209/240651 (20 Teşrin-i sani 1323/3 Aralık 1907). 
Klazomen Tahaffuzhanesi'ne yanaşan gemilerdeki yolcuların tahaffuzhaneye giriş ve çıkışı kayıkçılar tarafından sağlanıyordu. 1913 yılında, Urla iskelesi kayıkçıları Klazomen Tahaffuzhanesi tabibinin nüfuzunu kullanarak İzmir'den getirilen bir istimbot ile Pisagor adında bir kayıkçı ile ortak olduğu, yolcuların giriş ve çıkışını sağladığı ve bu işten menfaat sağladığı iddiasını dile getiren bir şikâyet telgrafinı İstanbul'a göndermiştir. ${ }^{57}$

\section{Klazomen Tahaffuzhanesi'nde Karantina Uygulamaları}

Servet-i Fünûn'da İzmir'e ilişkin olarak yayımlanan bir tanıtım yazısında İzmir'in Avrupa limanları ile olan ticari ilişkisi şu sözlerle tanımlanmaktadır: "Avrupa limanlarmm hemen kaffesinden gelen tüccar vapurlar limana uğrar. Dersaadetle bahren her gün münasebeti vardrr. İzmir'e en cok mabreclik eden Avrupa limanlar, Trieste, Londra, Marsilya, Odessa limanlardrr." ${ }^{58}$ İzmir, Akdeniz ticaret ağının bir parçası olduğu gibi özellikle Doğu Akdeniz karantina ağının da önemli bir parçasıdır. İzmir Körfezi’nin girişinde bulunan Urla'daki Klazomen Adası'nda kurulan tahaffuzhane bu karantina ağının temellerinden biridir. Klazomen Tahaffuzhanesi sadece gemilerin ve yolcuların karantina altına alındığı bir yer değildi, aynı zamanda İzmir'de bulunan yabancı ülkelerin postane çantaları ve telgrafları Hamidiye şirket vapuruyla tahaffuzhaneye gönderilerek orada tebhir ediliyordu. ${ }^{59} \mathrm{Bu}$ uygulama ile imparatorluk dışından gelebilecek salgin hastalık tehlikesi önlenmeye çalışıllyyordu.

19. yüzyıl Osmanlı arşiv belgeleri bize hem İstanbul'daki hem de yereldeki 144 Osmanlı yöneticilerinin Marsilya'dan Beyrut'a kadar Akdeniz'de ortaya çıkan salgin hastalık haberlerini yakından takip ettiklerini göstermektedir. ${ }^{60}$ Klazomen Tahaffuzhanesi, Akdeniz'de ortaya çıkan salgın hastalıklardan İstanbul'un korunması için kilit bir güvenlik noktasıdır. Hastalık şüphesi taşıyan gemiler Çanakkale Boğazı ve sonrasında İstanbul'a yol almadan önce mutlaka Klazomen Tahaffuzhanesi'nde kontrole tabi tutuluyorlardı. 1883 yilinda Misır'dan gelecek gemilerin Avrupa'daki tahaffuzhaneler gibi “kavaid-i sibhive” ye uygun bir şekilde inşa edilen ve içerisinde tatlı su kaynağı bulunan Klazomen Tahaffuzhanesi'ne veya Beyrut Tahaffuzhanesi'ne yönlendirilmesi gerektiği bildirilmiştir. Yemen'e gönderilen redif taburları Beyrut'ta tebhir makinesi olmadığı için memleketlerine dönmeden önce Taif vapuruyla doğrudan Klazomen Tahaffuzhane'sine

57 BOA, HR.İD: 1001/65 (16 Ağustos 1329/29 Ağustos 1913); BOA, HR.ID: 1001/67 (26 Eylül 1329/9 Ekim 1913); BOA, HR.ID: 1001/68 (6 Teşrin-i sani 1329/19 Kasım 1913).

58 Servet-i Fünun, 30 Kasim 1890, sy. 1, s. 8.

59 BOA, BEO: 1517/113708 (12 Rebiyyülevvel 1318/10 Temmuz 1900); Ahmet Asker, "Alman Konsolosluk Raporlarına Göre 1911-1914 Yılları Arasında Osmanlı Liman Kentlerinde Kolera", Osmanl Bilimi Araștırmalar, 22:1, 2021, s. 114.

60 BOA, DH.MKT: 74/13 (14.12.1310/29 Haziran 1893). 
gönderilmiş, burada karantinada tutulduktan ve eşyaları tebhir ve tathir edildikten sonra memleketlerine gönderilmişlerdir. ${ }^{61}$

1893 yllı Ocak ayında Hamburg limanından çıkarak Osmanlı limanlarına gelen tüm gemilerin Klazomen, Beyrut, Trablusgarp ve Avlonya tahaffuzhanelerinin birinde tam beş gün karantinada tutulmaları, Venedik ve Avusturya ve Macaristan sahillerinden çıkan gemilerin ve yolcuların üç gün, Karadeniz ve Romanya ve Bulgaristan'dan gelecek olanların ise yirmi dört saat karantinada tutulmaları, bu sırada yolcuların gerekli doktor kontrolleri yapıldıktan sonra yolcuların ve vapur tayfasının tüm eşyaları ve kıyafetlerinin etüv makinesinden geçirilerek dezenfekte edilmesi gerektiği talimatı verilmiştir. ${ }^{62} 1894$ y1lında Petersburg'da çıkan kolera salgını nedeniyle Finlandiya körfezinden Osmanlı limanlarina gelen gemilerin Klazomen, Beyrut veya Trablusgarp tahaffuzhanelerinin birinde on gün karantinada tutulmaları gerektiği Sıhhiye Nazırı tarafından ilgili dairelere bildirilmiştir. ${ }^{63}$

1893 y1linda Bingazi'de hyyarcıklı tifo, veba ve henüz ne olduğu tespit edilemeyen bir hastalığın ortaya çıkması nedeniyle Bingazi ve Trablusgarp sahillerinden çıkan gemilerin Malta'da ondört gün karantinada tutulduğu haberi üzerine Sadaret, Dahiliye Nezareti'ne Bingazi ve Trablusgarp'tan çıkan tüm gemilerin Klazomen veya Beyrut tahaffuzhanelerinde beş gün karantinaya tâbi tutularak yolcuların eşya ve elbiselerinin tebhir edilmesi gerektiğini bildirmiştir. ${ }^{64}$ 19. yüzyılın ikinci yarısında Osmanlı İmparatorluğu'nda yaşanan yoğun göç dalgası neticesinde muhacirlerin sağlık kontrolünden geçirilmesi ve eşyalarının dezenfekte edilmesi uygulamalanı tahaffuzhanelerde gerçekleştirilmiştir. ${ }^{65}$ Klazomen, Tuzla ve Sinop tahaffuzhaneleri muhacirlerin yoğunlaştı̆̆ı başlica sterilizasyon merkezleridir. ${ }^{66}$ Aydın Vilayeti bu yoğun göç dalgasından payını büyük ölçüde almıştır. ${ }^{67}$ Girit muhacirleri bu bölgeye sevk edilerek Klazomen Tahaffuzhanesi’nde

61 BOA, Y.A.HUS: 266/125 (21 Rebiyülahir 1310/12 Kasım 1892); BOA, Y.PRK.BŞK: 28/26 (21.04.1310/12 Kasım 1892); BOA, BEO: $3019 / 226385$ (13 Safer 1325/28 Mart 1907).

62 BOA, BEO: 134/9992 (23 Kanun-1 evvel 1308/4 Ocak 1893).

63 BOA, Y.MTV: 99/67 (9 Muharrem 1312/13 Temmuz 1894).

64 BOA, DH.MKT: 4/42 (3 Mart 1309/15 Mart 1893).

65 Müslüman nüfusun göç hareketlerine ilişkin bkz. Kemal H. Karpat, Osmanl Nüfusu (1830-1914), Timaş, İstanbul 2010, s. 151-161.

66 Kemal Arı, Büyük Mübadele: Türkiye’ye Zorunlu Gös (1923-1925), Tarih Vakfi Yurt Yayınları, İstanbul 2014, s. 96.

67 Kerim Tiryaki, "Osmanlı Devletinde Muhacirîn-i İslamiyenin İskânı; Problemler ve Çözüm Çabaları (1850-1900)", Gaziantep Üniversitesi, yayımlanmamıs doktora tezi, Sosyal Bilimler Enstitüsü, 2020, s. 234. Aydın Vilayeti'ndeki muhacir sayılarına ilişkin bkz. Ufuk Erdem, "Osmanlı'dan Cumhuriyet'e Muhacir Komisyonları ve Faaliyetleri (1860-1923)", yayımlanmamıss doktora tezi, Atatürk Üniversitesi, Sosyal Bilimler Enstitüsü, 2014, s. 37-38. Muhacirlerin ve mübadillerin sağlık kontrolünden geçirilmesi ve tahaffuzhanede eşyalarının dezenfekte edilmesi gibi uygulamalarına 1920lerde de devam edilmiştir. Özellikle 1923 yllında Türkiye ve Yunanistan 
sağlık taramalarından geçirilmiştir. 1893 yılında İstanbul'daki muhacirlerden yüzelli kişi Klazomen Tahaffuzhanesi'ne gönderilmiş ancak Aydın Valisi İzmir'deki şüpheli hastalık tehlikesi ortadan kalkıncaya kadar tahaffuzhaneye muhacir gönderilmemesini Dahiliye Nezareti'nden talep etmiştir. ${ }^{68}$

1894 y1linda Marsilya'daki kolera salg1nı neticesinde Fransa sahillerinden yolculu ve yolcusuz Osmanlı limanlarına gelecek tüm gemilerin Klazomen ve Beyrut tahaffuzhanelerinde beş gün karantinaya alınması ve gerekli dezenfeksiyon işlemlerinin yapılması gerektiği bildirilmiştir. ${ }^{69} 1899$ yılında Cezayir'in bazı şehirlerinden ortaya çıkan kolera illeti nedeniyle bu kentlerden gelecek olan gemilerin Klazomen, Beyrut ve Trablusgarp tahaffuzhanelerinde on gün boyunca karantinaya tabi tutulmaları gerektiği belirtilmiştir. ${ }^{70}$ Bulaşıcı hastalık taşıdığ1 düşünülen gemilerin tahaffuzhanelerde gereken müddet karantina beklemeden hareket etmelerine müsaade edilmemekteydi. Örneğin, 1900 yllinda İskenderiye'den gelerek Çanakkale Boğazı'ndan geçmek isteyen bir Alman gemisi bulaşık olduğu için Klazomen'e yönlendirilmişti. ${ }^{71} 1902$ yılında Hidıviye kumpanyasının İsmailiye vapurunun ateşçilerinden otuzsekiz yaşında Laz Hacı Hasan'1n dört gün süresince ağır hastalanması neticesinde gemi tabibinin yönlendirmesi ile gemi Klazomen

arasında gerçekleşen zorunlu göç sırasında karşı mübadiller Hilal-i Ahmer Cemiyeti tarafindan sağllk kontrolünden geçirilmişlerdir. 1923 yll Türk-Yunan mübadelesinde Midilli ve Girit’ten Ayvalık'a gelen mübadillerin sağlık kontrolü ve eşyalarının dezenfeksiyonu Klazomen Tahaffuzhanesi olmak üzere çeşitli tahaffuzhanelerde gerçekleştirilmiştir. Arı, a.g.e., s. 90; Elif Yılmaz, "Demirden Leblebi: Girit, Ayvalık’a Yerleşen Girit Mübadilleri’", Sosyoloji Dergisi, 3. Dizi, 22. Say1, 2011, s. 167-168; Özlem Sarıkaya, Murat Civaner, "Yirminci Yüzyllın Başlarında Anadolu'ya Göçler, Oluşan Halk Sağlığı Sorunları ve Sunulan Sağlık Hizmetleri”, Yeni Tip Taribi Araştırmalar, sy. 12-15, İstanbul 2006, s. 75-84; Tunca Özgişi, “Osmanlı Devleti’nden Türkiye Cumhuriyeti'ne Anadolu'ya Zorunlu Göçler ve Hilal-i Ahmer Cemiyeti'nin Yardım Faaliyetleri”, Uluslararasi Sosyal Arasttrmalar Dergisi, c. 7, sy. 31, 2014, s. 387-393; Mehmet Kaya, "Balkan Savaşları Sırasında Anadolu'ya Göçler ve Karşılaşılan Sorunlar", 100. Yılında Balkan Savaşlar (1912-1913): İbtilafl Duruşlar, Ed. Mustafa Türkeş, Türk Tarih Kurumu, c. 1, Ankara 2014, s. 295309.

68 BOA, DH.MKT: 115/47 (6 Ağustos 1309/18 Ağustos 1893). Balkan Savaşları sırasında da Rumeli'den Anadolu'ya gelen çoğunluğu elli altmış yaşlarında ve birkaç aylık bebeklerden yedi yaşına kadar çocuklardan oluşan muhacirler Klazomen Tahaffuzhanesi’ne gönderilmiştir. Aydın Valisi Nazım'n verdiği bilgiye göre, 1913 yllında Klazomen'de 1942 muhacirden 680'i ihtiyar kadın ve 618'i elli beş altmış yaşlarında erkek ve 644'ü küçük çocuktur. BOA, DH.MUI: 167/47 (7 Eylül 1329/20 Eylül 1913).

69 BOA, DH.MKT: 74/13 (15 Haziran 1309/27 Haziran 1894). Fransız basını da salgın hastalıkların hem Avrupa'da hem de Akdeniz'deki seyrini yakın takip ediyordu. Fransiz basinı da salgin hastalıkların hem Avrupa'da hem de Akdeniz'deki seyrini yakın takip ediyordu. 1890 yllında Journal Des Débats Politiques et Littéraires gazetesi hacıların güzergahını detaylandırırken hacıları taşıyan gemilerden İstanbul'a dönecek olanların Klazomen Tahaffuzhanesi'ne uğrayacağını belirtilmektedir. Journal Des Débats Politiques et Littéraires, 15 Ekim 1890, s. 3.

70 BOA, A.MKT.MHM: 579/16 (11 Receb 1317/15 Kasım 1899).

71 BOA, A.MKT.MHM: 580/10 (14 Muharrem 1318/14 Mayıs 1900). 
Tahaffuzhanesi'ne yanaşmıştır. ${ }^{72}$ Hasan'ın kolera olduğu ve hasta halde iken geminin hemen her yerine girip çıktığı anlaşıldıktan sonra gemideki yatak takımları ve birçok eşya yakılmıştır.

İzmir'in uluslararası ticaret ağı ile olan yakın bağlantısı neticesinde İzmir ve civarında çıkan salgın hastalık haberleri İzmir'deki konsoloslar tarafindan da an be an takip edilmekteydi. 1900 y1lı Ağustos ve 1901 yllı Eylül aylarında İzmir'deki Amerikan konsolosu Rufus W. Lane, Washington, D.C.'ye gönderdiği telgraflarda İzmir'de veba hastalığı şüphesinin henüz resmi olarak kanıtlanmadığını belirtmiş ancak yüklü miktarda elle toplanmış kuru meyvenin İzmir limanından Amerika Birleşik Devletleri'ne gönderildiğine dikkati çekmiştir. 1900 yılında İzmir ve civarındaki salgın hastalık nedeniyle Amerika Birleşik Devletleri, İzmir'den üzüm ve incir ithalatına boykot uygulamıştır. ${ }^{73}$ Lane, 1903 yılında İzmir'de elle toplanmış ve paketlenmiş yüklü miktarda kuru incirin Amerika'ya gönderilmek üzere hazırlandığını ve hastalıklara karşı dikkatli olunması gerektiğini bildirmektedir. ${ }^{74}$

1902 y1lında, İzmir'de şüpheli bir hastalıktan dolay1 Klazomen Tahaffuzhanesi'ne (lazaretto) nakledilen ve orada vefat eden bir kişinin ölüm nedeninin veba olduğu bakteriyolojik incelemeler neticesinde ortaya çı kmıştır. ${ }^{75}$ Aydın Vilayeti'ndeki telgraf ajansları Sadaret'e vebadan vefat eden bu kişinin İzmir rıhtımında bir kahvehanede çıraklık yapan Miletyadi adında on dört yaşında bir çocuk olduğunu bildirmektedir. Bu haber hem yerel yöneticileri hem de payitaht1 sıhhi tedbirlerin acilen alınması için harekete geçirmiştir. Sihhiye Nezareti, İzmir limanından çıkacak gemilerin Klazomen Tahaffuzhanesi'nde kırk sekiz saat ihtiyat karantinası altında tutulmasına karar vermiştir. Bu karantina süresince yolcuların ve gemi personelinin eşyaları ve elbiseleri etüv makinesi ile dezenfekte edilecek ve

72 BOA, A.MKT.MHM: 567/27 (4 Eylül 1318/17 Eylül 1902).

73 National Archives and Records Administration (NARA), No. 92, Consulate Of The United States, Smyrna, Turkey, September 28, 1901. 28 Sept. 1901. MS Turkey: Records of the U.S. Department of State, 1802-1949: Despatches From U.S. Consuls in Smyrna, Turkey, 1802-1906. National Archives (United States). Archives Unbound, https://link.gale.com/apps/doc/

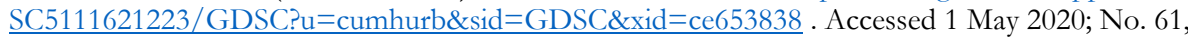
Consulate Of The United States, Smyrna, Turkey, August 28, 1900. August 28, 1900 - September 3, 1900. MS Turkey: Records of the U.S. Department of State, 1802-1949: Despatches From U.S. Consuls in Smyrna, Turkey, 1802-1906. National Archives (United States). Archives Unbound, https://link.gale.com/apps/doc/SC5111623779/GDSC?u=cumhurb\&sid=GDSC\&xid=71be1a e 5 . Accessed 1 May 2020.

74 NARA, No. 173, Consulate Of The United States, Smyrna, August 31, 1903. 31 Aug. 1903. MS Turkey: Records of the U.S. Department of State, 1802-1949: Despatches From U.S. Consuls in Smyrna, Turkey, 1802-1906. National Archives (United States). Archives Unbound, https://link.gale.com/apps/doc/SC5111621475/GDSC?u=cumhurb\&sid=GDSC\&xid=214aafc $\underline{\mathrm{d}}$. Accessed 1 May 2020.

75 BOA, A.MKT.MHM: 576/24 (7 Şevval 1319/17 Ocak 1902). 
veba hastalı̆̆ına yol açan gemilerdeki fareler itlaf edilecektir. ${ }^{76}$ Miletyadi'nin ölümünden on beş gün sonra İzmir'de herhangi başka bir vakaya rastlanılmaması ve gerekli tüm tedbirlerin (tedâbir-i fenniye) alınması neticesinde ihtiyat karantinası kaldırılmıştır. Dahiliye Nezareti, imparatorlukta her nerede veba ya da kolera şüphesi görülür ise valilerin hemen kaç kişinin tedavi altında olduğunu ve bu kişilerin karantina sürelerini gösteren detaylı raporlar ve istatistikler hazırlamaları gerektiğini belirtmiştir.

Osmanlı İmparatorluğu'nda salgın hastalıklara ilişkin ve kamu sağllğını korumaya yönelik olarak alınan önlemler zaman zaman şikayetlere de yol açmıştır. ${ }^{77}$ Örneğin, 1893 yllında, Milas'n Müslüman, Hristiyan ve Musevi cemaat liderleri Sihhiye Nezareti'ne ortak bir telgraf göndererek Milas'ta herhangi bir salgin hastalık izi görülmediği halde kendilerinin İzmir ile karadan ve deniz yoluyla bağlantılarının kesildiğini ve bu durumdan dolayı ahalinin telaş ve heyecan içerisinde bulunduğunu belirtmektedirler. ${ }^{78}$ Cemaat liderleri, alınan sıhhi tedbirlere karşı olmadıklarını ancak "vilayet dabilinde bulunmasindan baska bir günahı olmayan" kazalarında salgin hastalık varmış gibi kazalarının vilayet merkezi ile olan bağlantısının kopmasından duydukları rahatsızlı̆̆ dile getirmişlerdir. ${ }^{79}$ Osmanlı tahaffuzhanelerindeki uzun karantina süreleri de şikayetlere konu olmuştur. 1910 yllında Kafkasya'dan Türkistan'dan gelen sekiz yüz kırk kişi önce Sinop'ta on iki gün, Kavak Tahaffuzhanesi'nde yedi gün karantina beklemiş ardından Klazomen Tahaffuzhanesi'ne gelerek burada da sekiz gün karantinada kalmışlardır. Uzun karantina sürelerinden yakınan hacılar, Hacı Rıza'yı temsilci olarak seçmişler ve şikayetlerini telgrafla Sihhiye Nezareti'ne iletmişlerdir. Telgraflarında aralarında "başı ăgryan" bile olmadığını belirterek bir an evvel Cidde'ye gitmeyi arzuladıklarını ve gerekirse kalan karantina müddetlerini orada geçirebileceklerini belirtmişlerdir. Sihhiye Nezareti'nin Dahiliye Nezareti'ne "müstaceldir" notu ile gönderdiği yazıda "büccacon şiddetli galeyan göstererek tahaffuzhaneyi tahrib tessebbüsünde" bulunduklar1 ve bu hacıların arasında koleralıların bulunduğu ve hastalığın sirayetinin önlenmesi için karantinalarına devam edilmesi gerektiği bildirilmiştir. ${ }^{80}$

76 Servet-i Fünun, "Sefainde Tebhirat", 30/765, 21 Aralık 1905, s. 161-163; François Apéry, "Pierre Apéry (1852-1918): Un Pharmacien Face À La Peste Dans L'Empire Ottoman”, Osmanh Bilimi Araştırmalar, s. VI/1, 2004, s. 15-35; Lukas Engelmann, Christos Lynteris, Sulphuric Utopias: A History of Maritime Fumigation, The MIT Press, Cambridge 2020.

77 Nuran Yıldırım, "Osmanlı Coğrafyasında Karantina Uygulamalarına İsyanlar: "Karantina İstemezük"," Toplumsal Tarih, 300 Aralık, 2018, 16-25; Osman Şevki Uludağ, "Son Kapitülâsyonlardan Biri Karantina", Belleten, II/7,8, 1938, s. 457-458.

78 BOA, BEO: 266/19877 (13 Safer 1311/26 Ağustos 1893).

79 BOA, Y.MTV: 81/100 (8 Ağustos 1309/20 Ağustos 1893). Hacıların benzer itirazları için bkz. Ottoman-Southeast Asian Relations: Sources from the Ottoman Archives, Ed. İsmail Hakk1 Kadi-A.C.S. Peacock, vol. 1, Brill, Leiden 2020, s. 661-700.

80 BOA, DH.İD: 50/16 (7 Teşrin-i sani 1326/20 Kasım 1910); La Turquie, "Le Choléra: Measures de quarantine", 13 Ekim 1910, s. 2. 


\section{Sonuç}

Klazomen Tahaffuzhanesi'nin tarihi, 19. yüzyıl Akdenizi'nde ticaret, kamu sağlı̆̆1 ve insan hareketliliğinin tarihi ile birçok yönden kesişmektedir. Vapurların ve trenlerin kullanımı ve insan hareketliliği orantılı olarak artmış, kamu sağllğı, devletlerin iç meselesi olmaktan ziyade uluslararası sağlık konferanslarının ortak gündemi haline gelmiştir. Bu açıdan, Klazomen Tahaffuzhanesi, sadece İzmir ve art bölgesinin değil Doğu Akdeniz'in özellikle de İstanbul'un bulașıcı hastalıklardan korunmasını sağlayan bir işleve sahiptir. Bu nedenle, 19. yüzyılın ikinci yarısında yaygınlaşan etüv gibi yeni sihhi teknolojiler bu tahaffuzhanede uygulamaya konulmuş, şüpheli hastalık vakasına rastlanan ya da şüphe edilen gemiler Urla’ya yönlendirilmiştir.

Osmanlı yönetiminin yakından takip ettiği ve katıldığı uluslararası sağlık konferansları, sağlık uzmanlarının ve bakteriyologların salgın hastalıklara karşı tüm devletlerin ortak hareket ederek standart karantina ve tahaffuzhane uygulamalarının ortaya çıkmasını sağlamıştır. 19. yüzyılın ikinci yarısında ağırlıklı olarak Fransızca yayımlanan salgın hastalıklar, hijyen ve kamu sağlığı literatüründe Hac nedeniyle salgın hastalıkların Akdeniz'den Avrupa'ya sirayet ettiği vurgulanmaktadır. Bu bağlamda, binlerce hacının kontrol ve tedavi edildiği Klazomen Tahaffuzhanesi, Doğu Akdeniz’in güvenli bir limanı ve kilit konumda bir sağlık kontrol noktası olmuştur. Tahaffuzhane, coğrafi konumu ve mimari yapısı kadar idari yap1sı ve dönemin sağlık teknolojisini barındırması açısından Doğu Akdeniz’in başlıca tahaffuzhanelerinden biri haline gelmiştir.

Kurulduğu yıllardan 20. yüzyılın başlarına kadar çeşitli tadilatlar gören ve parlatorya gibi bazı yeni binaların da eklemlenmesi ile birlikte uluslararası bir sıhhi dezenfeksiyon kompleksine dönüşen Klazomen Tahaffuzhanesi, salgin hastalıkların yayılmasının önlenmesi ve sterilizasyon işlemlerinin dönemin sağlık teknolojilerine uygun bir şekilde yapılmasını sağlamıştır. 20. yüzyılın başında Maliye Nezareti ada arazisinin bir kısmını Maliye'ye aktarma talebinde bulunmuş ise de Sihhiye Nezareti, İzmir'in Urla kazasina bağlı olan Klazomen adasını "mevki-i coğrafisi bir manâ-i tabîyye teşkil eylemesine ve bir tahaffuzhaneye âid araziye hâricden hic kimsenin girmeye bak.ke olmamasina mebni" şeklinde tanımlayarak adanın tahaffuzhane kullanımı dışında başka amaçlarla kullanılmasının uygun olmadığını belirtmiştir. ${ }^{81}$

81 BOA, ML.EEM: 896/4 (11 Rebiyülevvel 1330/29 Şubat 1912). 


\section{Kaynaklar}

\section{Arşiv Kaynakları}

\section{Türkiye Cumhuriyeti Cumhurbaşkanlı̆̆ı Devlet Arşivleri Başkanlı̆̆ı-Başbakanlık} Osmanl Arşivi (BOA)

Babıâli Evrâk Odası (BEO): 255/19054; 227/16982; 3194/239543; 3205/240356; 45/3352; 3202/240106; 3207/240495; 3209/240651; 1517/113708; 3019/226385; 134/9992; $266 / 19877$.

Dâhiliye Nezâreti İdare Evrâkı (DH.ID): 50/16.

Dâhiliye Nezâreti Mektubî Kalemi (DH.MKT): 1755/95; 1771/90; 501/73; 74/13; 4/42; $115 / 47$.

Dâhiliye Nezâreti Muhaberât-1 Umumiye İdaresi (DH.MUI): 167/47.

Hâriciye Nezâreti İdare Evrâkı (HR.ID): 1001/65; 1001/67; 1001/68.

Hâriciye Nezâreti Umur-1 Hukukiye-i Muhtelite Müdiriyeti (HR.UHM): 118/35.

İrâde Husûsî (İ.HUS): 1/19; 160/101.

Mâliye Nezâreti Emlâk-1 Emiriyye Müdüriyeti (ML.EEM): 24/15; 896/4.

Meclis-i Vükelâ Mazbataları (MV): 66/72.

Sadâret Mühimme Kalemi Evrâk1 (A.MKT.MHM): 576/24; 571/10; 562/30; 578/8; 576/20; 566/14; 582/15; 588/17; 590/1; 572/23; 576/17; 572/13; 576/22; 579/16; $580 / 10 ; 567 / 27$.

Yıldız Başkitâbet Dairesi Marûzâtı (Y.PRK.BŞK): 28/26.

Yildız Husûsî Marûzât (Y.A.HUS): 263/59; 384/104; 266/125; 173/120.

Yıldız Mabeyn Erkanı ve Saray Görevlileri Maruzâtı (Y.PRK.SGE): 6/2.

Yıldız Mütenevvî Marûzât (Y.MTV): 99/67; 81/100.

\section{National Archives and Records Administration (NARA, Amerika Birleşik Devletleri)}

No. 61, Consulate Of The United States, Smyrna, Turkey, August 28, 1900. August 28, 1900 - September 3, 1900. MS Turkey: Records of the U.S. Department of State, 1802-1949: Despatches From U.S. Consuls in Smyrna, Turkey, 1802-1906. National Archives (United States). Archives Unbound, https://link.gale.com/ apps/doc/SC5111623779/GDSC?u=cumhurb\&sid=GDSC\&xid=71be1ae5

Accessed 1 May 2020.

No. 92, Consulate Of The United States, Smyrna, Turkey, September 28, 1901. 28 Sept. 1901. MS Turkey: Records of the U.S. Department of State, 1802-1949: Despatches From U.S. Consuls in Smyrna, Turkey, 1802-1906. National Archives (United States). Archives Unbound, https://link.gale.com/apps/doc/SC5111621223/ GDSC?u=cumhurb\&sid=GDSC\&xid=ce653838 . Accessed 1 May 2020.

No. 173, Consulate Of The United States, Smyrna, August 31, 1903. 31 Aug. 1903. MS Turkey: Records of the U.S. Department of State, 1802-1949: Despatches From U.S. Consuls in Smyrna, Turkey, 1802-1906. National Archives (United States). Archives Unbound, https://link.gale.com/apps/doc/SC5111621475/GDSC?u $=$ cumhurb\&sid=GDSC\&xid=214aafcd. Accessed 1 May 2020.

\section{Basin}

Hizmet, 2 Aralık 1893, s. 1; 2 Kasım 1890, s. 1. 
Journal Des Débats Politiques et Littéraires, 15 Ekim 1890, s. 3

Servet-i Fünun, "Sefainde Tebhirat", 30/765, 21 Aralık 1905, s. 161-163.

Servet-i Fünun, 30 Kasim 1890, sy. 1, s. 8.

\section{Diğer Kaynaklar}

1912 Beynelmilel Paris Mukavele-i Sıbhiyesi, Kader Matbaas1, Dersaadet 1339 (1920).

Apéry, François, "Pierre Apéry (1852-1918): Un Pharmacien Face À La Peste Dans L'Empire Ottoman", Osmanl Bilimi Arastirmalar, s. VI/1, 2004, s. 15-35.

Ar1, Kemal, Büyük Mübadele: Türkiye'ye Zorunlu Gọ̈s (1923-1925), Tarih Vakf1 Yurt Yayınlar1, İstanbul 2014.

“Asitane-i Aliyye'de tahaffuz̧hanenin inșasina kadar boğaz-ı bahr-ı sefid'de ittihaz. olunan karantina'da sefain-i Osmaniye ve ecnebiyenin tabi olduklar seraite dair talimat", 1252 (1836), Salname-i Hariciye, Sene 1318 (1900), s. 439.

Asker, Ahmet, “Alman Konsolosluk Raporlarına Göre 1911-1914 Yilları Arasında Osmanlı Liman Kentlerinde Kolera”, Osmanl Bilimi Arastırmalar, 22:1, 2021, s. 101-119.

Ayar, Mesut, “1900 İzmir ve 1901 İstanbul Salgınları Bağlamında Vebanın XX. Yüzyıl Başlarında Osmanlı İmparatorluğu'nda Devam Eden Etkisi”, History Studies, 2/2, 2010, s. 173-188.

Aydin Vilayet Sâlnâmesi, 1296 (1879).

Aydın Vilâyet Sâlnâmesi, R. 1307/H. 1308, İbrahim Câvid, Türk Tarih Kurumu, Ankara 2010.

Baldwin, Peter, Contagion and the State in Europe, 1830-1930, Cambridge University Press, Cambridge 2004.

Bashford, Alison, Imperial Hygiene: A Critical History of Colonialism, Nationalism and Public Health, Palgrave Macmillan, New York 2004.

Beyru, Rauf, 19. Ÿ̈̈ynlda İmir Kenti, Literatür, İstanbul 2011.

, Rauf, 19. Yüzyllda İmir'de Sağhlk Sorunlar ve Yaşam, İzmir Büyükşehir Belediyesi Kültür Yayınları, İzmir 2005.

Borel, Frederic, Étude d'bygiène Internationale: Choléra et peste dans le Pèlerinage Musulman, 1860 1903, Masson et Cie, Paris 1904.

Böke, Pelin, "İzmir Karantina Teşkilatının Kuruluşu ve Faaliyetleri (1840-1900)", CTTAD, VIII/18-19, s. 137-159.

Bulmuş, Birsen, Plague, Quarantines and Geopolitics in the Ottoman Empire, Edinburgh University Press, Edinburgh 2012.

Chiffoleau, Sylvia, "Les pèlerins, de La Mecque, les germes et la communauté internationale", Médecine/Sciences, sy. 27, 2011, s. 1121-1126.

Çadırcı, Musa, Tanzimat Döneminde Anadolu Kentleri’nin Sosyal ve Ekonomik Yapısı, Türk Tarih Kurumu, Ankara 1997.

Deschamps, Gaston, Sur Les Routes D'Asie, Armand Colin Et Cie, Paris 1894.

Doğan, Güner, “Osmanlı İmparatorluğu'nda Karantina Uygulaması ve Venedik Uluslararası Sihhiye Konferansı”, Hacettepe Üniversitesi Türkiyat Araștirmalar Dergisi, sy. 15, 2011, s. 91-109. 
Devlet-i Aliyye-i Osmaniye Tahaffųhanelerinde Düstur-ül-amel tutulmak üzere Meclis-i Umur-ı Sibbiye'nin 15 Haziran sene 1315 taribli ictimainda usul-i tebhir hakeknda kararlassdmlan talimat-ı umumiyenin tercümesidir, Matbaa-i Osmaniye, Dersadet 1315 (1897).

Engelmann, Lukas, Christos Lynteris, Sulphuric Utopias: A History of Maritime Fumigation, The MIT Press, Cambridge 2020.

Erdem, Ufuk, “Osmanlı'dan Cumhuriyet'e Muhacir Komisyonları ve Faaliyetleri (18601923), yayımlanmamış doktora tezi, Atatürk Üniversitesi, Sosyal Bilimler Enstitüsü, 2014.

Ersoy, Nermin, Yuksel Gungor, Aslihan Akpinar, "International Sanitary Conferences from the Ottoman perspective (1851-1838)", Hygiea Internationalis: An Interdisciplinary Journal for the History of Public Health, sy. 10, 2011, s. 53-79.

Etker, Şeref, "Paul-Louis Simond ve Bakteriyolojihane-i Osmani’nin Çemberlitaş’ta Açllş̧1 (21 Eylül

1911)", Osmanh Bilimi Araştırmalar, X/2, 2009, s. 13-33.

Ferrier, J., Des Lazarets Des Quarantaines et de la Conférence Internationale pour L'Organisation d'un Service Sanitaire En Orient, Chez Germer Baillière, Paris 1867.

Frangakis-Syrett, Elena, "The making of an Ottoman port: The quay of Izmir in the nineteenth century", The Journal of Transport History, 22/1, 2001, s. 23-46.

Geçili, Derya, "Osmanlı Devleti'nde Hacıların Gemilerle Nakledilmesi Sırasında Alınan Önlemler”, Tarih Okulu Dergisi, Haziran 2017, sy. XXX, s. 61-83.

Huber, Valeska, "The Unification of the Globe by Disease? The International Sanitary Conferences on Cholera, 1851-1894", The Historical Journal, vol. 49, No. 2, Jun., 2006), s. 453-476.

Howard-Jones, Norman, The Scientific Background of the International Sanitary Conferences (18311938), World Health Organization, Geneva 1975.

“Ilk Defa olarak Anadolu canibinde Ittihaz Olunan Karantina Kordonuna Dair Ferman Hümayun”, Evahir-i Safer 1254 (1838), Salname-i Hariciye, Sene 1318 (1900), s. 442.

İmir Şehir Rehberi, 1941, Ed. Suad Yurdkoru, İzmir Belediyesi Neşriyat1, İzmir 1941.

"Karantina memurlarmm keyfiyet-i memuriyetleriyle baklarnda defterdardan ve mal müdür ve memurlar taraflarndan olunacak muamelata dair talimat", 15 Muharrem 1267 (20 Kasim 1850); "Karantina rüsumu tarifesi", 3 Zilhicce 1272 (5 Ağustos 1856), Salname-i Hariciye, s. 664; Babriye-i Ticariye Salnamesi, 1329 (1913), s. 82-83.

Karc1, Erol, "Kolera ile Mücadelede Örnek Bir Sağlık Müessesesi: Sinop Tahaffuzhanesi ve Faaliyetleri (1892-1908), XVII. Türk Tarih Kongresi, Ankara: 15-17 Eylül 2014, Kongreye Sunulan Bildiriler, IV. Cilt - V. Kısım Osmanlı Taribi, Türk Tarih Kurumu, Ankara 2018, s. 1871-1893.

Karpat, Kemal H., Osmanh Nüfusu (1830-1914), Timaş, İstanbul 2010.

Kaya, Mehmet, "Balkan Savaşları Sırasında Anadolu’ya Göçler ve Karşılaşılan Sorunlar”, 100. Yilında Balkan Savaşlar (1912-1913): İbtilafl Duruşlar, c. 1, Ed. Mustafa Türkeş, Türk Tarih Kurumu, Ankara 2014, s. 295-309.

Kontente, Léon, Smyrne et l'Occident, Yvelinéedition, Montigny-le-Bretonneux 2005.

Low, Michael Christopher, "Empire and the Hajj: Pilgrims, Plagues, and Pan-Islam Under British Surveillance, 1865-1908”, International Journal of Middle East Studies, sy. 40, 2008, s. 269-290. 
Midhat, Ahmed, "Devlet-i Aliyye-i Osmaniyye'de Karantina, Yani Usûl-ü Tahaffuz̧n Tarihçesi”, Salnâme-i Nezaret-i Umur-ı Hariciye, 1318 (1902), s. 436-471.

Ottoman-Southeast Asian Relations: Sources from the Ottoman Archives, vol. 1, Ed. İsmail Hakk1 Kad1-A.C.S. Peacock, Brill, Leiden 2020.

Ömer, Besim, Akil Muhtar, Koleraya Karşı Ittihazı Lazım Gelen Tedâbir ve Etıbbaya Rebber, Arşak Garviyan Matbaası, İstanbul 1328 (1910).

Özgişi, Tunca, “Osmanlı Devleti'nden Türkiye Cumhuriyeti’ne Anadolu’ya Zorunlu Göçler ve Hilal-i Ahmer Cemiyeti'nin Yardım Faaliyetleri”, Uluslararası Sosyal Arassttrmalar Dergisi, c. 7, sy. 31, 2014, s. 387-393.

Panzac, Daniel, Osmanl Imparatorluğu'nda Veba (1700-1850), Tarih Vakfi Yurt Yayınları, İstanbul 1997.

Proceedings of the International Sanitary Conference Opened At Constantinople on the 13th February 1866.

Promitzer, Christian, "Prevention and stigma: the sanitary control of Muslim pilgrims from the Balkans, 1830-1914", Mediterranean Quarantines, 1750-1914: Space, Identity and Power, Ed. John Chircop-Francisco Javier Martines, Manchester University Press, Manchester 2018, s. 145-170.

Proust, A., La Défense de L'Europe contre Le Choléra, G. Masson, Paris 1892.

Rapport de la Commission Chargée Par Le Conseil de Santé d'Élaborer un Projet de Tarif des Droits Sanitaires dans L'Empire Ottoman, Imperimerie Centrale, Constantinople 1866.

Sarıkaya, Özlem, Murat Civaner, 'Yirminci Yüzyılın Başlarında Anadolu’ya Göçler, Oluşan Halk Sağlığı Sorunları ve Sunulan Sağlık Hizmetleri”, Yeni Tip Taribi Arastırmalar, sy. 12-15, İstanbul, 2006, s. 75-84.

Sarıyıldız, Gülden, Oya Dağlar Macar, "Cholera, Pilgramage, and International Politics of Sanitation: The Quarantine Station on the Island of Kamaran”, Plague and Contagion in the Islamic Mediterranean, Ed. Nükhet Varlık, ArcHumanities Press, Croydon 2017, s. 243-275.

, “Osmanlilar'da Hifzissihha”, Türkiye Diyanet Vakefi İslam Ansiklopedisi, Cilt 17, İstanbul 1998, s. 319-312.

, "Karantina", Türkiye Diyanet Vakfi İslam Ansiklopedisi, Cilt 24, İstanbul 2001, s. $463-$ 465.

, Hicaz Karantina Teşkilâtı (1865-1914), Türk Tarih Kurumu, Ankara 1996.

Serçe, Erkan, Tanzimat'tan Cumburiyet'e İzmir'de Belediye (1868-1945), Dokuz Eylül Yayınları, İzmir 1998.

Şahin, Kâmil, "XIX. Yüzyıl Sonlarında Kastamonu'da Hastahaneler”, İkinci Kastamonu Kültür Semposyumu Bildirileri (18-20 Eylül 2003), Kastamonu Valiliği, Ankara 2005, s. 119-124.

Şehsuvaroğlu, Bedi N., "Türkiye Karantina Tarihine Giriş I", İstanbul Üniversitesi Tipp Fakültesi Mecmuası, c. 20, sy. 3, 1957, s. 418-444.

, “Türkiye Karantina Tarihine Giriş III", İstanbul Üniversitesi Tip Fakültesi Mecmuasi, Cilt 21, sy. 1, 1958, s. 146-169.

Tiryaki, Kerim, “Osmanlı Devletinde Muhacirîn-i İslamiyenin İskânı; Problemler ve Çözüm Çabaları (1850-1900)”, Gaziantep Üniversitesi, yayımlanmamıs doktora tezi, Sosyal Bilimler Enstitüsü, 2020. 
Tulasoğlu, Gülay, ““"Humble Efforts in Search of Reform”: Consuls, Pashas, and Quarantine in Early-Tanzimat Salonica”, Well-Connected Domains: Towards an Entangled Ottoman History, Ed. Pascal W. Firges vd., Brill, Leiden 2014, s. 188-207.

Tuncbilek, Gonca Z., "Quarantine (d) Space: Urla-Izmir (Smyrna) Island”, Space and Culture, Vol. 23 (3), 2020, s. 246-252.

Uludağ, Osman Şevki, "Son Kapitülâsyonlardan Biri Karantina”, Belleten, II/7,8, 1938, s. 445-467.

Ünver, A. Süheyl, “Osmanlı Tababeti ve Tanzimat Hakkında Yeni Notlar”, Tanথimat, MEB, İstanbul 1999, s. 947-959.

Watts, Sheldon, "Cholera and the maritime environment of Great Britain, India and the Suez Canal: 1866-1883", International Journal of Environmental Studies, sy. 63:1, 2006, s. 19-38.

Yaşayanlar, İsmail, “Osmanlı Devleti’nde Kamu Sağlı̆̆ının Kurumsallaşmasında Koleranın Etkisi”, Osmanlidan Cumburiyet'e Salgin Hastalıklar ve Kamu Sağhlğ, Ed. Burcu Kurtİsmail Yaşayanlar, Tarih Vakfı Yurt Yayınları, İstanbul 2017, s. 2-24.

, “Osmanlı Döneminde Uygulanan Deniz Karantinasına İlişkin Bazı Bilgiler”, Âb-ı Hayât’ Aramak: Gönül Tekin'e Armağan, Ed. Ozan Kolbaş-Orçun Üçer, Yeditepe, İstanbul 2018, s. 737-761.

Yıldırım, Nuran, “"Karantina İstemezük” Osmanlı Coğrafyasında Karantina Uygulamalarına İsyanlar", 14. Yüzyzldan Cumburiyet'e Hastahklar, Hastaneler, Kurumlar: Sağllk Taribi Yazıları I, Tarih Vakfi Yurt Yayınları, İstanbul 2014, s. 70-88.

, "Disinfecting Stations in Ottoman Empire", Science in Islamic Civilisation: Proceedings of the International Symposia, Science Institutions in Islamic Civilisation and Science and Technology in the Turkish and Islamic World, Ed. Ekmeleddin İhsanoğlu-Feza Günergun, IRCICA, İstanbul 2000, s. 267-277.

, “Tersane-i Amire Fabrikaları'nda Tebhir Makinası/Etüv Üretimi ve Kullanımı”, Dünü ve Bugünü ile Halic Sempozyumu Bildirileri, 22-23 Mayss 2003, Ed. Süleyman Faruk Göncüoğlu, Kadir Has Üniversitesi Yayınları, İstanbul 2004, s. 421-429.

Yllmaz, Ebru, "A Discussion on the Spatial Representation of the Ottoman Modernization: Urla Quarantine Building", Online Journal of Art and Design, volume 8, issue 4, October 2020, s. 1-24.

Yılmaz, Elif, “Demirden Leblebi: Girit, Ayvalık’a Yerleşen Girit Mübadilleri”, Sosyoloji Dergisi, sy. 3:22, 2011, s. 157-189.

Zandi-Sayek, Sibel, Ottoman Izmir: The Rise of a Cosmopolitan Port (1840-1880), University of Minnesota Press, London 2012.

\section{Summary}

The nineteenth-century world saw the professionalization of medical services and sanitary applications, and the use of scientific methods to prevent contagious diseases and outbreaks. These methods included the construction of quarantines, the establishment of sanitary cordons, and the usage of sanitary technologies. The International Sanitary Conferences held in Europe in the $19^{\text {th }}$ century also fostered the standardization of health 
policies to curb contagious diseases and pandemics. Since outbreaks of contagious diseases occurred frequently in the Ottoman Empire, Ottoman officials genuinely attempted to follow the contemporary and global quarantine practices in the $19^{\text {th }}$ century. The International Sanitary Conference of 1866 convened in Istanbul was one example illustrating that Ottoman officials aimed to improve sanitation policies in the Empire and establish, institutionalize and secure public health (sibhat-i umumiye) through quarantine stations specifically constructed in the port-cities where maritime trade activities were dense.

With the help of steamships and trainlines, trade networks expanded in the nineteenth century, resulting in an increase not only in the exchange of goods and the flow of people, but also the spread of contagious diseases from cholera to plague. Therefore, the security policies of the maritime borders and the role of customs and quarantine stations became more important than before. The implementation of sanitary policies in the Ottoman Empire included the construction of quarantine stations, starting with the establishment of quarantine in Istanbul in 1831, the usage of the new sanitary technologies such as sterilization (etüv) and disinfection (pulverizatör) machines for preventing contagious diseases and controlling the maritime traders and passengers. Port-cities of the Empire such as Izmir, Salonica, and Beirut had busy maritime trade in the $19^{\text {th }}$ century, and were the first places to construct the quarantine stations and implement sanitary practices and technologies. After Istanbul, Izmir was the first city that had the professional quarantine organization in the Ottoman Empire. The first quarantine station in Izmir was constructed in 1846 close to the city center but it was burned down in the fire of 1848. Between 1866-1869 the quarantine (Tahaffuzhane) was relocated to Klazomen Island, today Urla, at the entrance of the Gulf of Izmir. Urla Quarantine became an important part of the quarantine network in the Eastern Mediterranean. Izmir's Klazomen Quarantine was one of the first quarantines that had used new sanitation technology; the first one was the Kavak Quarantine in Istanbul. Based on research in the collections of the Ottoman Archives (BOA) in Istanbul, this paper examines the implementation of sanitary policies in Urla (Klazomenai) Quarantine in Izmir in the late Ottoman Empire. This article analyzes the role of Klazomen Quarantine that played to prevent infectious diseases such as cholera and plague from the perspectives of international quarantine applications and public health.

The archival documents indicate the imperial and local officials in the Ottoman Empire were closely following the maritime activities for any news or information about contagious diseases that occurred in the Mediterranean from Marseille to Beirut. Urla Quarantine was important for securing the imperial center from contagious diseases because almost every ship that had a passenger with a suspicious health issue was to drop anchor in Urla and be checked by the Quarantine officials. The Ottoman officials emphasized the importance of Urla Quarantine repeatedly because this Quarantine played a very crucial role to prevent the contagious diseases along the sea route of the pilgrimage (Hajj) to Hijaz. Every year during the Hajj, thousands of pilgrims 
were isolated and treated in Urla Quarantine with the help of medical officials, and pilgrims' items and clothes were disinfected by the pressured steam of the sterilization machine.

One of the major problems concerning the Quarantine was its capacity. The Ottoman officials frequently discussed possible solutions to increase this limited capacity of the Quarantine because of the increasing numbers of pilgrims every year in the late Ottoman Empire. Due to budgetary issues, the officials decided to use tents instead of constructing new buildings attached to the Quarantine. The Ottoman quarantines including Urla Quarantine were part of a larger quarantine network in the Mediterranean. The quarantine stations were places for isolation, disinfection, and sterilization, and were also where new sanitation technologies were used to curb contagious diseases. The quarantines established in the Ottoman Empire in the nineteenth century with the aim of securing public health were also a result of the professionalization of medical practices, particularly bacteriology, and urbanization, including infrastructural projects led by municipalities and local officials. 